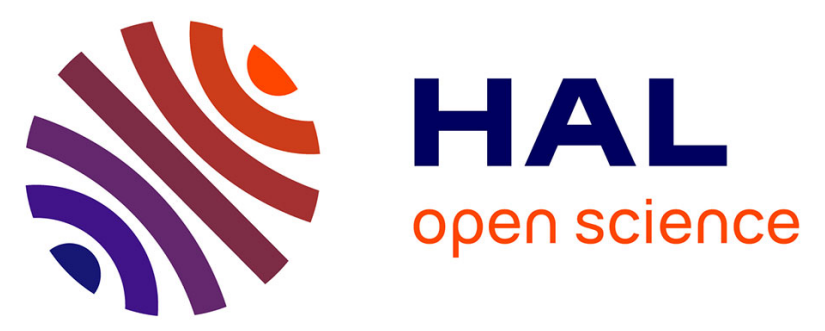

\title{
Evolutionary insights into the genomic organization of major ribosomal DNA in ant chromosomes
}

Gisele Amaro Teixeira, Hilton Jeferson Alves Cardoso de Aguiar, Frédéric

Petitclerc, Jérôme Orivel, Denilce Meneses Lopes, Luisa Antonia Campos

Barros

\section{To cite this version:}

Gisele Amaro Teixeira, Hilton Jeferson Alves Cardoso de Aguiar, Frédéric Petitclerc, Jérôme Orivel, Denilce Meneses Lopes, et al.. Evolutionary insights into the genomic organization of major ribosomal DNA in ant chromosomes. Insect Molecular Biology, 2021. hal-03369943

\section{HAL Id: hal-03369943 https://hal.science/hal-03369943}

Submitted on 7 Oct 2021

HAL is a multi-disciplinary open access archive for the deposit and dissemination of scientific research documents, whether they are published or not. The documents may come from teaching and research institutions in France or abroad, or from public or private research centers.
L'archive ouverte pluridisciplinaire HAL, est destinée au dépôt et à la diffusion de documents scientifiques de niveau recherche, publiés ou non, émanant des établissements d'enseignement et de recherche français ou étrangers, des laboratoires publics ou privés. 
4 Gisele Amaro Teixeira ${ }^{1,2}$, Hilton Jeferson Alves Cardoso de Aguiar $^{3 *}$, Frédéric

$5 \quad$ Petitclerc $^{4}$, Jérôme Orivel ${ }^{4}$, Denilce Meneses Lopes ${ }^{2}$, Luísa Antônia Campos Barros ${ }^{3}$

6

71 Programa de Pós-graduação em Biologia Celular e Estrutural, Universidade Federal 8 de Viçosa, Viçosa, MG 36570-000, Brazil.

92 Laboratório de Citogenética de Insetos, Departamento de Biologia Geral,

10 Universidade Federal de Viçosa, Viçosa, MG 36570-900, Brazil.

11 3-Universidade Federal do Amapá, Campus Binacional - Oiapoque, n³051, Bairro

12 Universidade, 68980-000, Oiapoque, Amapá, Brazil.

134 CNRS, UMR EcoFoG, AgroParisTech, CIRAD, INRA, Université de Guyane,

14 Université des Antilles, Campus Agronomique, BP 316, 97379 Kourou Cedex, France.

16 Short running title: Evolution of rDNA genes in ant chromosomes

$17 *$ Corresponding author

18 E-mail: hilton.aguiar@hotmail.com 


\section{Abstract}

2 The major rDNA genes are composed of tandem repeats and are part of the nucleolus

3 organizing regions (NORs). They are highly conserved and therefore useful in

4 understanding the evolutionary patterns of chromosomal locations. The evolutionary

5 dynamics of the karyotype may affect the organization of rDNA genes within

6 chromosomes. In this study, we physically mapped 18S rDNA genes in 13 Neotropical

7 ant species from four subfamilies using fluorescence in situ hybridization. Furthermore,

8 a survey of published rDNA cytogenetic data for 50 additional species was performed,

9 which allowed us to detect the evolutionary patterns of these genes in ant chromosomes.

10 Species from the Neotropical, Palearctic, and Australian regions, comprising a total of 63

11 species from 19 genera within six subfamilies, were analyzed. Most of the species (48 out

12 of 63) had rDNA genes restricted to a single chromosome pair in their intrachromosomal

13 regions. The position of rDNA genes within the chromosomes appears to hinder their

14 dispersal throughout the genome, as translocations and ectopic recombination are

15 uncommon in intrachromosomal regions because they can generate meiotic

16 abnormalities. Therefore, rDNA genes restricted to a single chromosome pair seem to be

17 a plesiomorphic feature in ants, while multiple rDNA sites, observed in distinct

18 subfamilies, may have independent origins in different genera.

20 Keywords: Evolution - ribosomal DNA - gene dispersion - Formicidae - chromosome

21 rearrangements - physical mapping 


\section{Introduction}

Eukaryotic genomes have repetitive tandem sequences such as in the major

3 ribosomal RNA genes $(45 \mathrm{~S}=18 \mathrm{~S}+5.8 \mathrm{~S}+28 \mathrm{~S})$, herein denominated rDNA, which

4 contain highly conserved genic sequences and are therefore useful as molecular genetic

5 markers, allowing comparisons across distant taxa. However, intergenic spacers vary in

6 both sequence and length (Long and Dawid, 1980; Sumner, 2003; Symonová, 2019). The

$745 \mathrm{~S}$ ribosomal genes are part of the nucleolus organizing regions (NORs) and are located

8 in portions of the DNA that, after their condensation, usually appear as secondary

9 constrictions on metaphase chromosomes (Sumner, 2003).

10 The silver nitrate impregnation technique (Ag-NOR banding) shows only

11 transcriptionally active NORs by staining nuclear acid proteins involved in transcription

12 (Howell and Black, 1980; reviewed by Sumner, 2003). Species with multiple rDNA

13 clusters do not usually exhibit silver-staining in all clusters (reviewed by Sumner, 2003;

14 Vicari et al., 2008). However, it must be assumed that if a species has only a single NOR

15 (or single 45S rDNA gene site), then it will be transcriptionally active, as evidenced for

16 different organisms (Dobigny et al., 2002; Barros et al., 2015; Falcione et al., 2018;

17 Cholak et al., 2020; Malimpensa et al., 2020).

Intercellular and interindividual variations are frequently detected by the Ag-NOR

banding method (Zurita et al., 1997; Cross et al., 2003; Walker et al., 2014; Schmid et

20 al., 2017). However, the use of this technique in ant species has not produced reliable

21 results owing to low repeatability, difficulty in obtaining good-quality markings, and the appearance of unspecified marks on heterochromatic regions of many chromosomes,

23 which makes using this procedure unsatisfactory and inconclusive (Imai et al., 1992;

24 Hirai et al., 1994; Lorite et al., 1997; Barros et al., 2009, 2015; Aguiar et al., 2017). 
Since the 1980s, molecular cytogenetic tools have been used to study karyotypes.

2 For example, fluorescence in situ hybridization (FISH) has proven to be an effective and

3 precise tool for physically mapping specific DNA sequences within chromosomes

4 (reviewed by Levsky and Singer, 2003; Liehr, 2017). The rDNA genes can be located in

5 single or multiple chromosome pairs (Sochorová et al., 2018). In several organisms,

6 studies of these genes have pointed to chromosomal differences within species complexes

7 (Mantovani et al., 2005; Barbosa et al., 2017; Dutra et al., 2020) and between species

8 with similar karyotypes (Panzera et al., 2012; Golub et al., 2015; Gokhman et al., 2016).

9 As a consequence, inferences can be made based on chromosomal rearrangements that

10 shape the chromosomal evolution of a species (Roy et al., 2005; Nguyen et al., 2010;

11 Britton-Davidian et al., 2011; Cabral-de-Mello et al., 2011; Dutrillaux and Dutrillaux,

12 2012; Roa and Guerra, 2012; Menezes et al., 2019; Degrandi et al., 2020).

In ants, the physical mapping of rDNA genes using the FISH technique was first described in Australian ants by Hirai et al. $(1994,1996)$. Since then, the number of studies mapping these genes has increased (Mariano et al., 2008; Santos et al., 2016; Micolino et al., 2019a; Teixeira et al., 2020) and other repetitive sequences, such as telomeres

17 (Meyne et al., 1995; Pereira et al., 2018; Micolino et al., 2020; Castro et al., 2020), satellite DNA (Lorite et al., 2004; Huang et al., 2016), 5S ribosomal genes (Aguiar et al., 2017), and microsatellites (Barros et al., 2018; Micolino et al., 2019b), have been mapped in the chromosomes using the FISH technique. To date, molecular cytogenetic studies on rDNA genes in ants have improved understanding of chromosomal evolution and phylogeny, and provided taxonomic resolutions for different ant groups (Hirai et al., 1994, 1996; Santos et al., 2010, 2016). 
1 (Ectatomminae, Formicinae, Myrmicinae, and Ponerinae). In addition, we reviewed

2 previous molecular cytogenetic data related to rDNA gene clusters $(45 \mathrm{~S}, 18 \mathrm{~S}$, or $28 \mathrm{~S})$ in

3 ants. Using these data, we investigated whether the number and location of the ribosomal

4 gene clusters followed a specific pattern or were randomly distributed in order to

5 understand the genomic organization and evolutionary dynamics of these genes in ants.

6

$7 \quad$ Results

8

91 - Chromosome mapping of $18 S$ rDNA clusters in 13 Neotropical ant species

10

11 All of the studied ant species presented only a single 18S rDNA site that was co-

12 localized with GC-rich regions $\left(\mathrm{CMA}_{3}{ }^{+}\right)($Table 2$)$, while AT-rich regions $\left(\mathrm{DAPI}^{+}\right)$were

13 not detected in any species. Most of the species presented GC-rich rDNA genes in the

14 intrachromosomal regions (pericentromeric or interstitial), including Pseudoponera

15 gilberti (Kempf, 1960) (Fig. 1A, S1A), Anochetus targionii Emery, 1894 (Fig. 1B, S1B),

16 Odontomachus haematodus (Linnaeus, 1758) (Fig. 1C, D, S1C), Odontomachus bauri

17 Emery, 1892 (Fig 1E, S1D), Pheidole germaini Emery, 1896 (Fig. 2A, S2A),

18 Crematogaster longispina Emery, 1890 (Fig. 2B, S2B), Solenopsis geminata (Fabricius,

19 1804) (Fig. 2C, D, S2C), Myrmicocrypta sp. (Fig. 2E, S2D), and Acromyrmex echinatior

20 (Forel, 1899) (Fig. 2F). Additional GC-rich bands only occurred in P. gilberti in the

21 pericentromeric region of the $3^{\text {rd }}$ and $4^{\text {th }}$ metacentric chromosome pairs (Fig. S1B).

22 Differences in rDNA cluster sizes between homologous chromosomes were observed in

23 heterozygous O. bauri individuals. One of the homologous chromosomes showed clusters

24 approximately twice the size of those in the other chromosome (Fig. 1F, S1E). A male 
1 individual bearing a chromosome with minor GC-rich bands was analyzed (Fig. S1F).

2 Homozygous individuals with duplicated clusters were not observed.

3

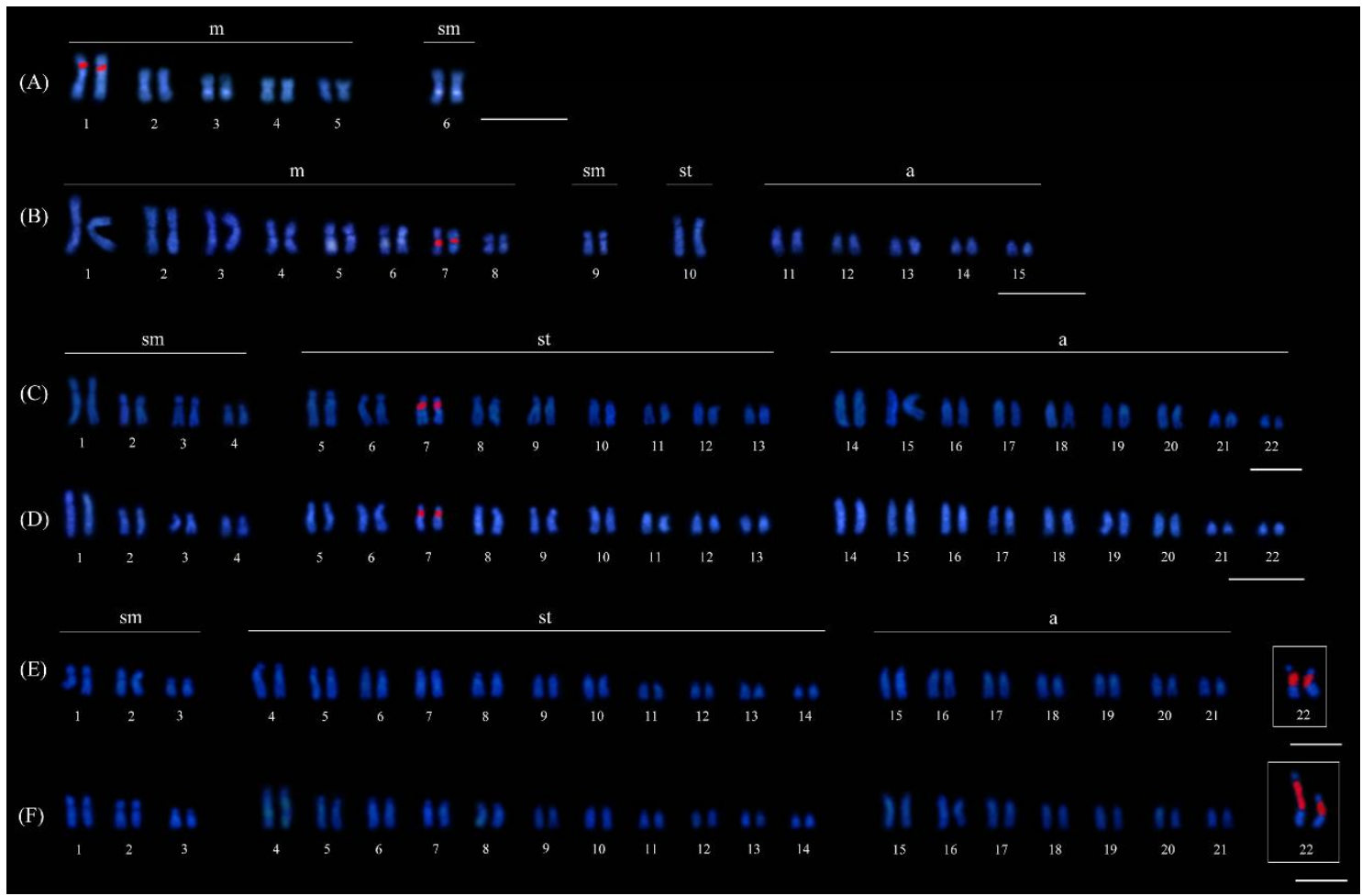

5 Figure 1. Fluorescence in situ hybridization with $18 \mathrm{~S}$ rDNA probe (red blocks) of

6 Ponerinae ants: (A) Pseudoponera gilberti (2n=12), (B) Anochetus targionii ( $2 n=30),(C$,

7 D) Odontomachus haematodus (2n=44, Brazil and French Guiana, respectively), (E, F)

8 Odontomachus bauri $(2 \mathrm{n}=44)$. In the last species, the $18 \mathrm{~S}$ rDNA site was located on the

9 long arm of the polymorphic chromosomal pair. The boxes show a polymorphic

10 subtelocentric pair in (E) in the homozygous state, and (F) in the heterozygous state. Bars

$11=5 \mu \mathrm{m}$. 


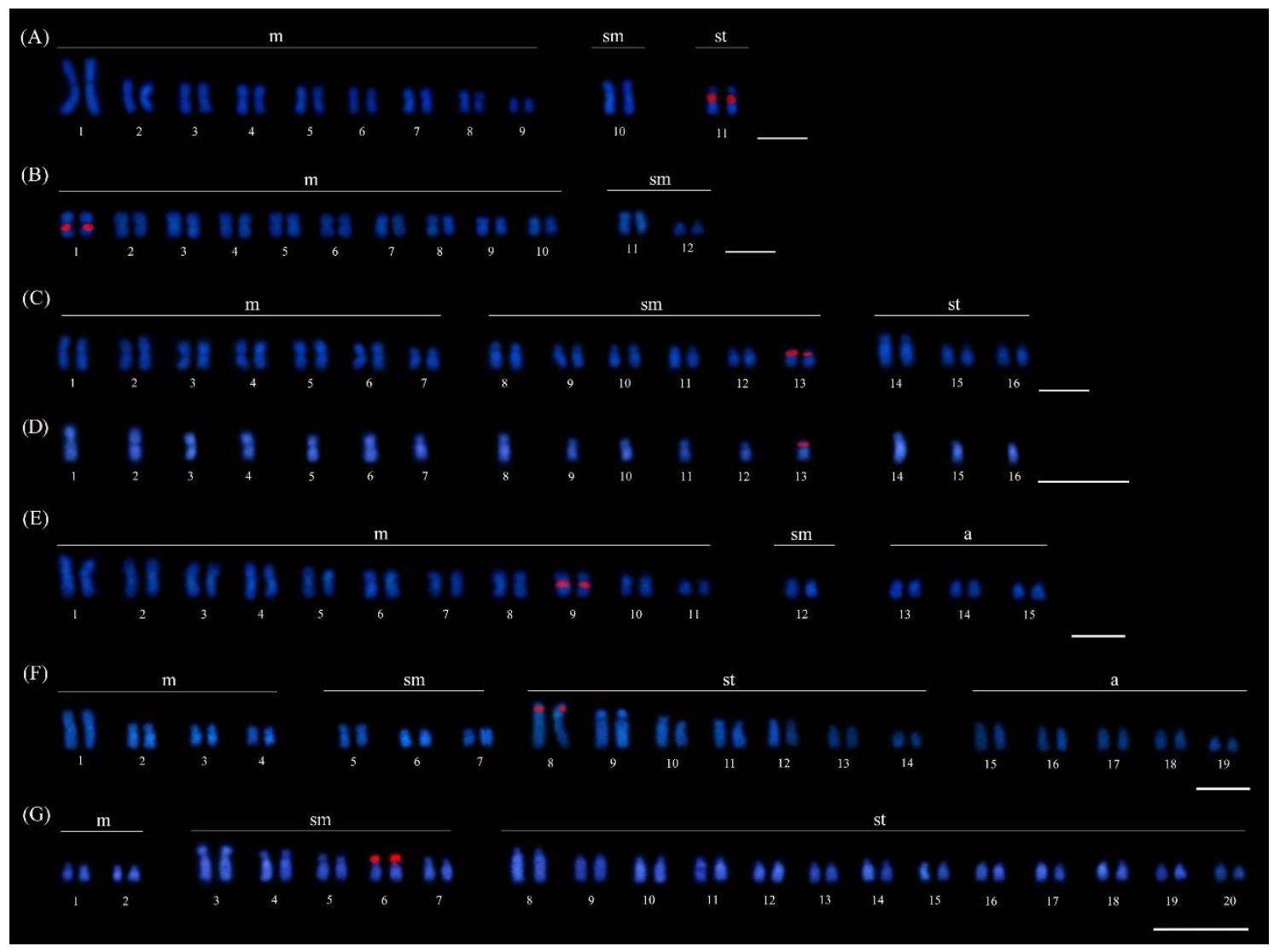

2 Figure 2. Fluorescence in situ hybridization with $18 \mathrm{~S}$ rDNA probe (red blocks) of

3 Myrmicinae ants: (A) Pheidole germaini (2n=22), (B) Crematogaster longispina

$4 \quad(2 n=24),(C)$ Solenopsis geminata $(2 n=32)$ and (D) Solenopsis geminata $(n=16),(E)$

5 Myrmicocrypta sp. $(2 \mathrm{n}=30)$, (F) Acromyrmex echinatior $(2 \mathrm{n}=38)$, (G) Strumigenys

6 diabola $(2 \mathrm{n}=40)$. Bars $=5 \mu \mathrm{m}$.

The remaining species showed GC-rich 18S rDNA clusters across the entire

9 chromosome arm, occupying either the long arm, as in Gnamptogenys tortuolosa (Smith,

10 1858) (Fig. 3A, S3A), or residing in the short arm, as in Strumigenys diabola Bolton,

112000 (Fig. 2G, S2E), Camponotus atriceps (Smith, 1858) (Fig. 3B, S3B), and Gigantiops

12 destructor (Fabricius, 1804) (Fig. 3C, S3C, D). Heteromorphism of 18S rDNA clusters

13 was detected in all of the analyzed $C$. atriceps and $G$. tortuolosa individuals. In the latter

14 species, the heteromorphism of the NOR resulted in differences in total size between 
1 homologous chromosomes, which changed their morphology such that one was

2 submetacentric while the other was subtelocentric. In G. destructor, additional GC-rich

3 bands were located in the interstitial region of the long arm of the largest subtelocentric

4 chromosome pair (Fig. S3C, D).

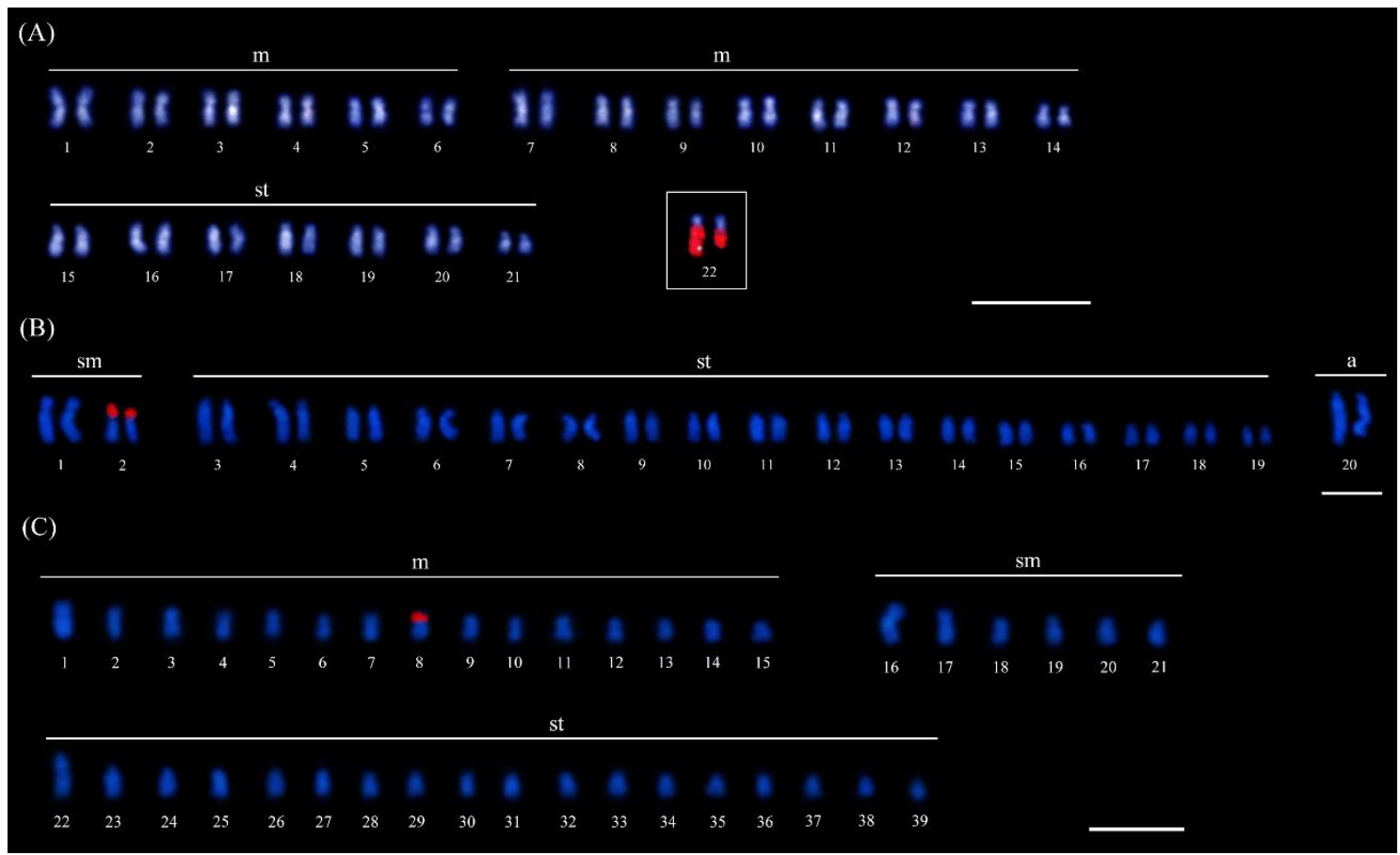

7 Figure 3. Fluorescence in situ hybridization with $18 \mathrm{~S}$ rDNA probe (red blocks) of an

8 Ectatomminae ant (A) Gnamptogenys tortuolosa $(2 \mathrm{n}=44)$, and Formicinae ants (B)

9 Camponotus atriceps $(2 \mathrm{n}=40)$ and $(\mathrm{C})$ Gigantiops destructor $(\mathrm{n}=39)$. In G. tortuolosa,

10 the box shows a remarkable size heteromorphism of $18 \mathrm{~S}$ rDNA clusters between

11 homologs. Bars: $5 \mu \mathrm{m}$.

132 - Chromosome mapping review of rDNA clusters in ants

Cytogenetic data available in the literature related to the rDNA genes of 50 ant

16 species from 12 genera and six subfamilies were reviewed (Table 2; Fig. 4). Most data

17 were concentrated on Neotropic ants, with information on 33 species, while the Palearctic 
1 and Australian regions had data on only one and 16 species, respectively. A single rDNA

2 site localized in the intrachromosomal region was observed in most species (Fig. 4A, B).

3 However, Camponotus renggeri Emery, 1894, Dinoponera gigantea (Perty, 1833), and

4 most of the studied Myrmecia species presented multiple rDNA sites over the entire short

5 chromosome arm. The subfamily Myrmicinae possessed most of the rDNA data, and the

6 Myrmeciinae subfamily showed a different pattern in relation to other subfamilies with

7 multiple rDNA sites observed in the majority of species (Fig. 4C). Dolichoderus

8 voraginosus Mackay, 1993 did not show any co-localization of 18S rDNA clusters and

9 GC-rich bands. Figure 5 summarizes the available data on the number and position of

10 NORs in ant species and the phylogenetic relationships among these species, and is based

11 on the published molecular phylogenies.

13 Discussion

1 - Patterns of rDNA clusters in the karyotypes of specific ant groups

Specific rDNA patterns can be observed in the karyotypes of some ant groups where several species have been studied. In species of the genus Dolichoderus, the

19 chromosome numbers range from $2 \mathrm{n}=10$ to 58 , and a single rDNA site in the interstitial 20 region has been observed in the majority of the investigated species. However, there are 21 two exceptions: D. voraginosus and Dolichoderus attelaboides (Fabricius, 1775), where 22 the rDNA clusters are located in the terminal region of the long arm and in the short arm, 23 respectively (Santos et al., 2016).

24 Despite the chromosomal variation observed in Gnamptogenys spp. ( $2 \mathrm{n}=24$ to 44 ),

25 they all have a single rDNA site in the intrachromosomal region (Teixeira et al., 2020). 
1 Even Gnamptogenys moelleri (Forel, 1912), a species with differing chromosome

2 numbers between two populations ( $2 n=34$ and 44$)$, has a single intrachromosomal rDNA

3 site. Gnamptogenys tortuolosa is an exception, with rDNA clusters occurring over the

4 entire long arm (this study). In the genus Anochetus, the chromosome number ranges

5 from $2 \mathrm{n}=30$ to 46 , and a single pericentromeric rDNA site has been observed (Santos $e t$

6 al., 2010).

All analyzed fungus-farming ants (Attina) had a single rDNA site located in the

8 intrachromosomal region (Table 2). In the genus Mycetophylax, although chromosome

9 number differs among species ( $2 n=26$ to 36 ), a single rDNA site is located in the

10 pericentromeric or terminal region in all the species of the genus (Micolino et al., 2019a).

11 The leaf-cutting ants are considered the most derived among the Attina species (Schultz

12 and Brady, 2008). Atta spp. $(2 \mathrm{n}=22)$ have a single rDNA site in the interstitial region and

13 Acromyrmex spp. $(2 \mathrm{n}=38)$ have a single rDNA site in the terminal region (Barros et al.,

14 2015, 2016; Teixeira et al., 2017). Acromyrmex striatus (Roger, 1863), a sister group of

15 the leaf-cutting ants, has $2 \mathrm{n}=22$ and pericentromeric rDNA clusters that are not located

16 on the same chromosome pair relative to that in Atta spp. (Cristiano et al., 2013; Teixeira

17 et al., 2017). In A. echinatior (2n=38), rDNA clusters are located in the interstitial region

18 of the same pair as observed in other Acromyrmex spp. (this study).

19 The chromosome number of the Australian bulldog ants is highly variable,

20 ranging from $2 \mathrm{n}=2$ to 76 (Imai et al., 1994). In addition, Myrmecia spp. present

21 remarkable patterns of multiple $28 \mathrm{~S}$ rDNA clusters that are highly dispersed throughout

22 their genomes. The number of rDNA sites increases with the chromosome number of the

23 species. This suggests several ribosomal gene amplification events have occurred in the

24 different species of Myrmecia and that they have accumulated in karyotypes throughout

25 the evolution of the genus. Only four out of 16 species from this monophyletic genus 
1 have the entire arm or intrachromosomal rDNA clusters restricted to a single pair of

2 chromosomes (Hirai et al., 1994, 1996; Hirai, 2020). This pattern is observed in species

3 with small chromosome numbers, which suggests that a single NOR is plesiomorphic

4 among Myrmecia (Hirai, 2020).

Carpenter ants (Camponotus) from the subgenus Myrmothrix have $2 n=40$

6 chromosomes, with its studied species having a single rDNA site in the terminal region.

7 Camponotus renggeri is the only exception, having an additional rDNA cluster at the

8 terminal region of a medium-sized subtelocentric pair (Aguiar et al., 2017).

In the giant ants of the genus Dinoponera, two contrasting patterns have been

10 observed: D. gigantea $(2 \mathrm{n}=82)$ has multiple rDNA sites located on its short chromosome 11 arms (Aguiar et al., 2011), whereas Dinoponera lucida Emery, 1901 has a higher 12 chromosome number $(2 \mathrm{n}=120)$, but only a single rDNA site restricted to the 13 intrachromosomal region of its largest chromosome pair (Mariano et al., 2008).

14 Homeology patterns among chromosomal pairs bearing ribosomal genes can be 15 detected in a few ant genera, such as Gnamptogenys (striatula group), Camponotus 16 (Myrmothrix), Atta, and Acromyrmex (Table 2). However, it is speculative to infer such 17 homeology patterns for the entire Formicidae family. Ants constitute an ultra-diverse monophyletic group with more than 13,800 described species (Bolton, 2020). They show

19 a wide range of karyotype variation both in number $(2 n=2$ to $2 n=120)$ and chromosomal morphology (reviewed by Lorite and Palomeque, 2010; Mariano et al., 2019). ant genome 
2 and six subfamilies, together with information on their phylogenetic relationships,

3 demonstrated that a single pair of chromosomes bearing the GC-rich rDNA clusters is the

4 most frequent trait among the studied species, regardless of the chromosome number

5 (Table 1, Fig. 4A). Genomes carrying rDNA clusters in more than a single chromosome

6 pair have been observed in non-related taxa, such as D. gigantea (Aguiar et al., 2011), C.

7 renggeri (Aguiar et al., 2017), and Myrmecia spp. (Hirai et al., 1994, 1996). We

8 hypothesize that having a single rDNA site should be considered a plesiomorphic trait

9 because multiple rDNA sites were observed in different non-related lineages that do not

10 share exclusive common ancestry and appear de novo throughout the Formicidae family. 
(A)

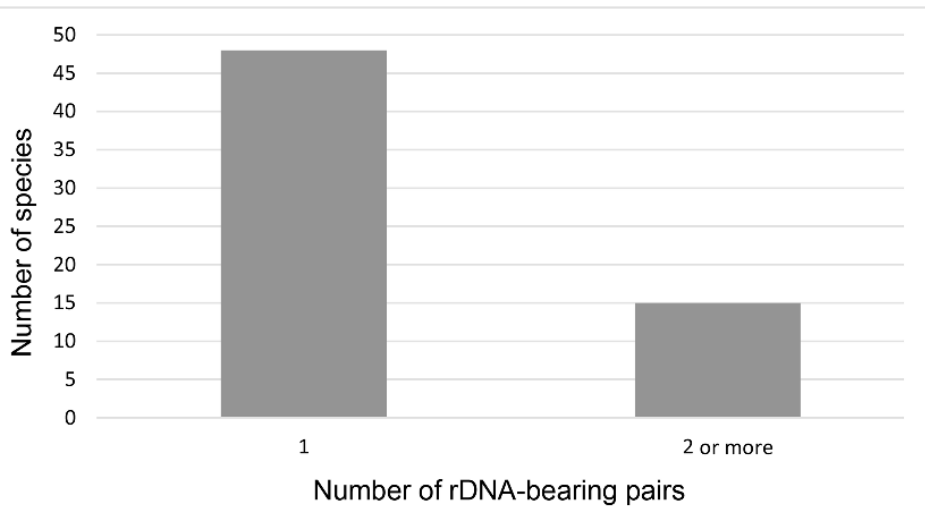

(B)

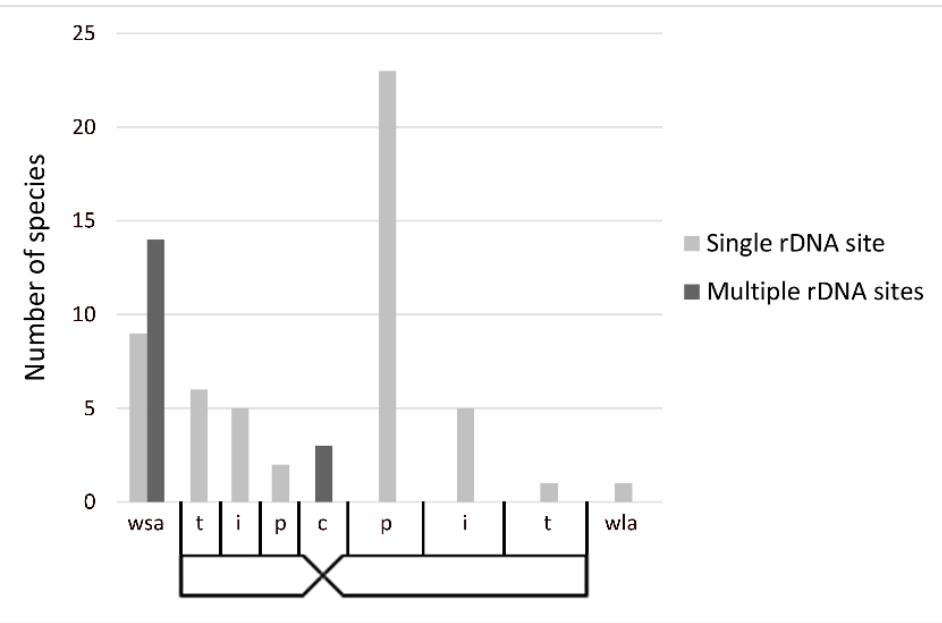

(C)

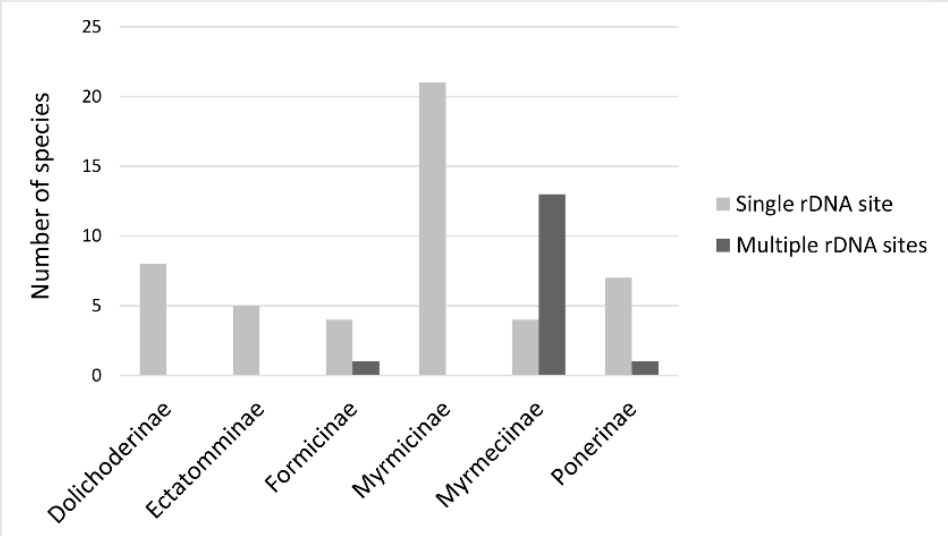

2 Figure 4. Summary of available molecular cytogenetic data (this study and in the

3 literature) concerning rDNA genes in ant species: (A) number of species with single and

4 multiple rDNA sites in a karyotype, (B) location of rDNA genes in chromosomes of ant

5 species, considering the following chromosomal regions: c, centromeric region; $\mathrm{p}$,

6 pericentromeric region; i, interstitial region; $t$, terminal region; wsa, whole short arm; wla, 
1 whole long arm, and (C) number of species with single and multiple rDNA sites by

2 subfamilies of Formicidae.

In eukaryotes, it is common to observe variations in the number of rDNA clusters

4 and the location of these genes in the chromosomes within genera (Sánchez-Gea et al., 5 2000; Gross et al., 2010; Cabral-de-Mello et al., 2011; Gokhman et al., 2014; Mazzoleni 6 et al., 2018), among populations (Panzera et al., 2014; Ferreti et al., 2019; Menezes et 7 al., 2019), and sexes of the same species (Nakayama et al., 2001; Št'áhlavský et al., 2018).

8 The possession of terminal rDNA clusters seems to be a common trait among mammals,

9 fish, and mollusks, but less so in arthropods (Sochorová et al., 2018). Within the ultra10 diverse insect group, the location of rDNA clusters may follow distinct patterns in its two 11 largest orders; terminal rDNA sites are more abundant in Coleoptera, whereas 12 pericentromeric rDNA clusters are more frequent in Orthoptera (Sochorová et al., 2018).

13 In Formicidae, terminal rDNA sites are a less common feature and all species with 14 multiple rDNA clusters show these genes in the entire short chromosome arms including 15 terminal/subterminal regions, such as C. renggeri, D. gigantea, and Myrmecia spp. 16 (Aguiar et al., 2011, 2017; Hirai et al., 1994, 1996).

17 Different hypotheses have been proposed to explain the cytogenetic pattern 18 (conservative or variable) of these rDNA clusters in the genome of several organisms. 19 Such hypotheses are linked to the specific locations of these rDNA clusters on the 20 chromosomes. Rearrangements, such as translocations, unequal exchange, and ectopic 21 recombination mechanisms (i.e., between non-homologous chromosomes), which can 22 lead to gene dispersion or increases in number in the genome, are more likely in the 23 terminal/subterminal regions of chromosomes and are uncommon in the 24 intrachromosomal regions (Martins and Wasko, 2004; Mantovani et al., 2005; Nguyen et 25 al., 2010; Roy and Guerra, 2012; Hirai, 2020). 
2 proposed that translocations are more likely to occur in telomeric regions because of their 3 proximity within the interphase nucleus, which originates from the ordering of

4 chromosomes according to Rabl's model. Effects due to the location of ribosomal genes

5 in relation to their dispersion in the karyotype were also observed in Coleoptera

6 (Dutrillaux et al., 2016) and primates (Gerbault-Seureau et al., 2017). These authors

7 argued that translocations in the interstitial position could result in abnormal meiosis and,

8 therefore, unbalanced gametes. In contrast, translocations in terminal positions may

9 increase the number of rDNA genes in the genome. This would lead to fewer meiotic

10 abnormalities and highlights the selection for interstitial rDNA site stability (Dutrillaux

11 et al., 2016; Gerbault-Seureau et al., 2017).

12 Ectopic recombination is another mechanism suggested to explain the rDNA

13 patterning in moths and butterflies (Nguyen et al., 2010) and plants (Roa and Guerra,

14 2012). It is also included in the recent model proposed by Hirai (2020). In this model,

15 two mechanisms are important: the "site effect" and the "molecular effect." The former

16 allows terminal region associations due to the proximity of these regions in a meiotic

17 bouquet. The "site effect" is a precondition for the "molecular effect," which refers to

18 systems of affinity/non-affinity due to the similarity between rDNA sequences with other

19 repetitive sequences. Thus, rDNA clusters in the terminal regions tend to associate with

20 other repetitive sequences of non-homologous chromosomes more easily, facilitating the

21 occurrence of ectopic recombination and dispersion of these genes in the genome (Hirai,

22 2020).

23 There are reports of species with multiple rDNA clusters associated with the

24 centromeres of acrocentric chromosomes (Cazaux et al., 2011). In the recent model

25 proposed by Hirai (2020), the centromeric region of acrocentric chromosomes 
1 (chromosomes with a short and heterochromatic arm) that have rDNA genes associated

2 with the centromere may behave as subterminal regions. Therefore, such an arrangement

3 would also facilitate eventual associations of rDNA genes with other repetitive sequences

4 and the occurrence of ectopic recombination, which leads to their dispersal in the genome

5 (for details, see Hirai, 2020).

6 The ant rDNA chromosome evolution seems to be in accordance with the above-

7 mentioned hypothesis about dispersal and NOR location because the single rDNA

8 clusters of most studied species are interstitial or pericentromeric (Fig. 4B). In ant species,

9 terminal rDNA clusters are prone to rearrangements that lead to their dispersal.

10 Camponotus renggeri (Aguiar et al., 2017), D. gigantea (Aguiar et al., 2011), and

11 Myrmecia spp. present multiple NORs in the entire short chromosome arms including

12 terminal/subterminal regions, which facilitates the association of these genes with the

13 heterochromatic sequences of other non-homologous acrocentric chromosomes during

14 meiosis and the subsequent occurrence of ectopic recombination (Hirai, 2020). This

15 pattern may be applicable to different ant groups. In addition, inversions have been shown

16 to change the position of rDNA genes in A. echinatior (this study), Dolichoderus spp.

17 (Santos et al., 2016), and Myrmecia spp. (Hirai et al., 1996). 


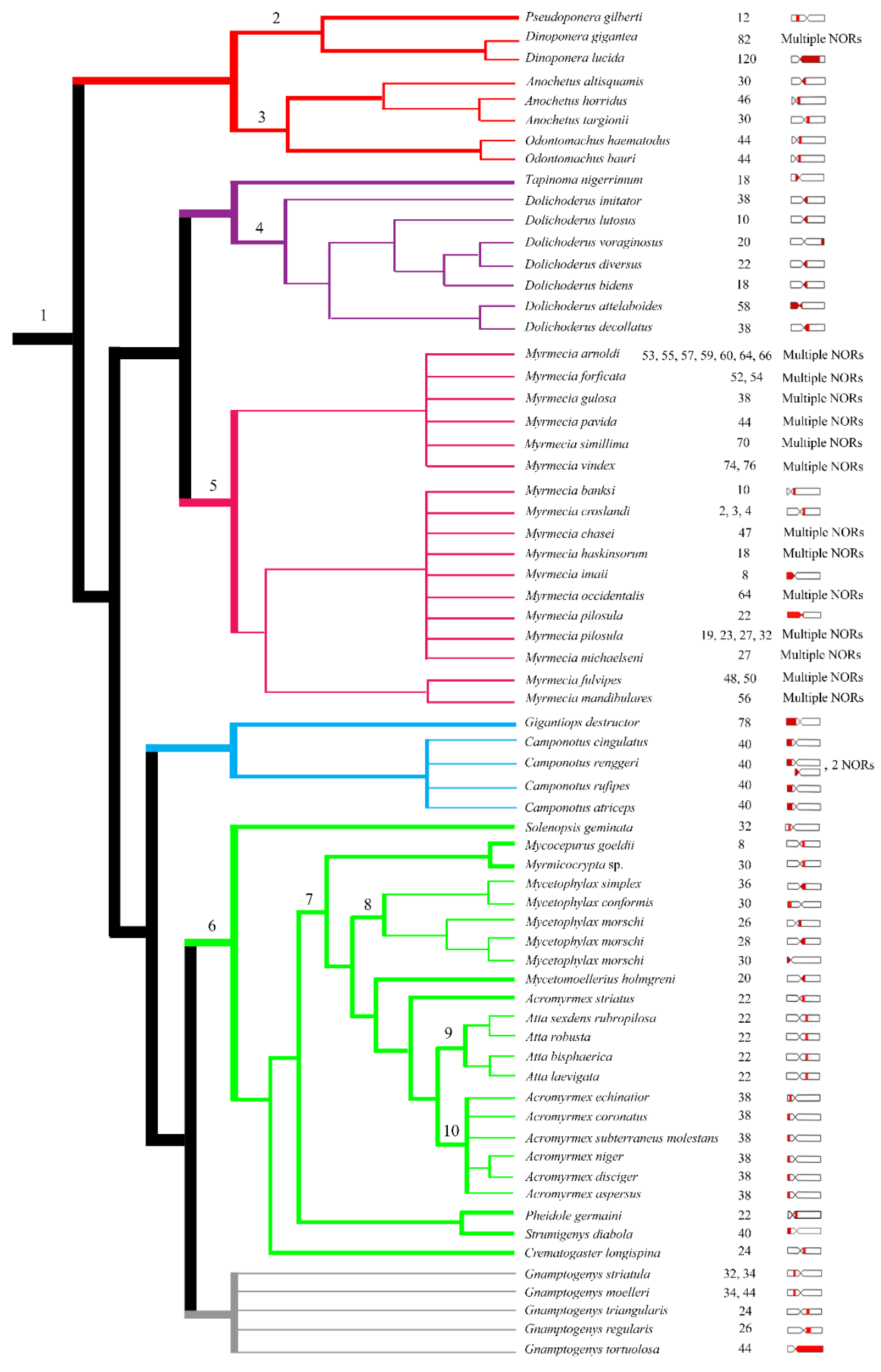

2 Figure 5. Summary of available data (this study and literature) concerning the number

3 and position of rDNA genes in ant species, along with their degree of relatedness and

4 diploid chromosome numbers. Ideograms of rDNA-bearing chromosomes show number 
1 and location (terminal, interstitial, pericentromeric or centromeric) of rDNA clusters (red)

2 in the haploid complement. Phylogenetic relationships are based on 1- Moreau and Bell

3 (2013), 2 - Schmidt (2013), 3 - Larabee et al. (2016), 4 - Santos et al. (2016), 5 - Hasegawa

4 and Crozier (2006), 6 - Ward et al. (2015), 7 - Solomon et al. (2019), 8 - Micolino et al.

5 (2019a), 9 - Bacci et al. (2009), 10 - Queiroz (2015). Colours of phylogenetic branches

6 indicate the following subfamilies: red, Ponerinae; purple, Dolichoderinae; pink,

7 Myrmeciinae; blue, Formicinae; green, Myrmicinae; gray, Ectatomminae.

A single rDNA site located in the terminal region or entire chromosomal arm was

9 observed in some ant species. The repetitive sequences in the subterminal/terminal

10 chromosome regions probably do not form affinity systems with ribosomal genes (the so-

11 called molecular effect; for details, see Hirai, 2020) in these species. Therefore, rDNA

12 clusters are restricted to a single chromosomal pair. Future studies focusing on the

13 characterization of repetitive sequences that make up the heterochromatin of these species

14 will help clarify this hypothesis.

15 Size heteromorphisms are frequent in karyotypes where the rDNA clusters have 16 terminal positions in the chromosomes, as reported in this study (G. tortuolosa and $C$. 17 atriceps) as well as in other ants (Aguiar et al., 2017) and insects in general (Cabral-de-

18 Mello et al., 2011; Maryańska-Nadachowska et al., 2016; Andrade-Souza et al., 2018).

19 Subtle variations in the size of the rDNA clusters between homologous chromosomes can

20 be observed as a result of late condensation during cell division (Sumner, 2003).

21 However, large variations, such as those mentioned above, at the terminal region on the

22 chromosome are usually related to duplications/deletions as a result of unequal exchange

23 (Schubert and Lysack, 2011). It is believed that exchanges are less common in

24 intrachromosomal regions (Hirai, 2020). 
1 Table 1. Summary of the available molecular cytogenetic data concerning major ribosomal genes (45S, 28S or 18S) detected by FISH in ants

\begin{tabular}{|c|c|c|c|c|c|}
\hline Ant species & $2 n /(n)$ & $\begin{array}{c}\text { Location of rDNA genes } \\
\text { in karyotype }\end{array}$ & Ideogram & $\begin{array}{c}\text { Co-localization } \\
\text { CMA3/rDNA }\end{array}$ & $\begin{array}{c}\text { Reference } \\
\mathrm{CMA}_{3} / \mathrm{rDNA}\end{array}$ \\
\hline \multicolumn{6}{|c|}{ Neotropical ants } \\
\hline \multicolumn{6}{|l|}{ Subfamily Myrmicinae } \\
\hline Acromyrmex aspersus & 38 & Largest subtelocentric pair & & Yes & Teixeira et al. (2017) \\
\hline Acromyrmex coronatus & 38 & Largest subtelocentric pair & & Yes & Barros et al. (2016) \\
\hline Acromyrmex disciger & 38 & Largest subtelocentric pair & & Yes & Barros et al. (2016) \\
\hline Acromyrmex echinatior & 38 & Largest subtelocentric pair & & Yes & $\begin{array}{l}\text { Barros et al. (2016)/ } \\
\text { Present study }\end{array}$ \\
\hline Acromyrmex niger & 38 & Largest subtelocentric pair & & Yes $^{a}$ & Barros et al. (2016) \\
\hline Acromyrmex striatus & 22 & 2nd metacentric pair & & Yes $^{\text {a }}$ & $\begin{array}{l}\text { Cristiano et al. (2013)/ } \\
\text { Teixeira et al. (2017) }\end{array}$ \\
\hline $\begin{array}{c}\text { Acromyrmex subterraneus } \\
\text { molestans }\end{array}$ & 38 & Largest subtelocentric pair & & Yes & Teixeira et al. (2017) \\
\hline Atta bisphaerica & 22 & 4th metacentric pair & & Yes & $\begin{array}{l}\text { Barros et al. (2014)/ } \\
\text { Teixeira et al. (2017) }\end{array}$ \\
\hline Atta laevigata & 22 & 4th metacentric pair & & Yes & $\begin{array}{l}\text { Barros et al. (2014)/ } \\
\text { Teixeira et al. (2017) }\end{array}$ \\
\hline Atta robusta & 22 & 4th metacentric pair & & Yes & Barros et al. (2015) \\
\hline Atta sexdens rubropilosa & 22 & 4th metacentric pair & $T$ & Yes & $\begin{array}{l}\text { Barros et al. (2014)/ } \\
\text { Teixeira et al. (2017) }\end{array}$ \\
\hline
\end{tabular}


Table 1. Cont.

\begin{tabular}{|c|c|c|c|c|c|}
\hline Ant species & $2 n /(n)$ & $\begin{array}{c}\text { Localization of rDNA genes } \\
\text { in karyotype }\end{array}$ & Ideogram & $\begin{array}{c}\text { Co-localization } \\
\text { CMA3/rDNA }\end{array}$ & $\begin{array}{c}\text { Reference } \\
\text { CMA }_{3} / \text { rDNA }\end{array}$ \\
\hline Crematogaster longispina & 24 & Largest metacentric pair & & Yes & Present study \\
\hline Mycetophylax conformis & 30 & 11th metacentric pair & & Yes & $\begin{array}{l}\text { Cardoso et al. (2014)/ } \\
\text { Micolino et al. (2019a) }\end{array}$ \\
\hline Mycetophylax morschi & 26 & 2nd submetacentric pair & & - & Micolino et al. (2019a) \\
\hline Mycetophylax morschi & 28 & 7th metacentric pair & & - & Micolino et al. (2019a) \\
\hline Mycetophylax morschi & 30 & Acrocentric pair & & - & Micolino et al. (2019a) \\
\hline Mycetophylax simplex & 36 & Smallest metacentric pair & & Yes & $\begin{array}{l}\text { Cardoso et al. (2014)/ } \\
\text { Micolino et al. (2019a) }\end{array}$ \\
\hline Mycocepurus goeldii & 8 & 2nd metacentric pair & & Yes $^{\text {a }}$ & $\begin{array}{l}\text { Barros et al. (2010)/ } \\
\text { Barros et al. (2012) }\end{array}$ \\
\hline Myrmicocrypta sp. & 30 & 9th metacentric pair & & Yes & Present study \\
\hline Pheidole germaini & 22 & Subtelocentric pair & & Yes & Present study \\
\hline Solenopsis geminata & 32 & Smallest submetacentric pair & & Yes & Present study \\
\hline Strumigenys diabola & 40 & 4th submetacentric pair & & Yes & Present study \\
\hline Trachymyrmex holmgreni & 20 & 4th metacentric pair & & Yes & Barros et al. (2018) \\
\hline \multicolumn{6}{|l|}{ Subfamily Formicinae } \\
\hline Camponotus atriceps $^{\mathrm{c}}$ & 40 & 2nd submetacentric pair & & Yes & Present study \\
\hline
\end{tabular}


Table 1. Cont.

\begin{tabular}{|c|c|c|c|c|c|}
\hline Ant species & $2 n /(n)$ & $\begin{array}{c}\text { Localization of rDNA genes } \\
\text { in karyotype }\end{array}$ & Ideogram & $\begin{array}{c}\text { Co-localization } \\
\text { CMA3/rDNA }\end{array}$ & $\begin{array}{c}\text { Reference } \\
\text { CMA }_{3} / \text { rDNA }\end{array}$ \\
\hline Camponotus cingulatus $^{\mathrm{c}}$ & 40 & 2nd submetacentric pair & & Yes & Aguiar et al. (2017) \\
\hline Camponotus renggeri & 40 & $\begin{array}{l}\text { 2nd submetacentric pair } \\
\text { and medium-sized } \\
\text { subtelocentric pair }\end{array}$ & & Yes & Aguiar et al. (2017) \\
\hline Camponotus rufipes $^{\mathrm{c}}$ & 40 & 2nd submetacentric pair & & Yes & Aguiar et al. (2017) \\
\hline Gigantiops destructor & (39) & 8th metacentric pair & & Yes $^{\text {a }}$ & Present study \\
\hline \multicolumn{6}{|l|}{ Subfamily Ponerinae } \\
\hline Anochetus altisquamis ${ }^{\mathrm{c}}$ & 30 & 3rd submetacentric pair & & - & Santos et al. (2010) \\
\hline Anochetus horridus ${ }^{\mathrm{c}}$ & 46 & 4th telocentric pair & & - & Santos et al. (2010) \\
\hline Anochetus targionii & 30 & 7th metacentric pair & & Yes & Present study \\
\hline Dinoponera gigantea & 82 & Multiple pairs & - & - & Aguiar et al. (2011) \\
\hline Dinoponera lucida & (59) & Largest pair $\left(\mathrm{A}^{\mathrm{Mt}}\right)$ & & Yes & Mariano et al. (2008) \\
\hline Odontomachus bauri ${ }^{\mathrm{d}}$ & $44 /(22)$ & 2nd subtelocentric pair & & Yes & Present study \\
\hline Odontomachus haematodus & 44 & 3rd subtelocentric pair & & Yes & Present study \\
\hline Pseudoponera gilberti & 22 & Largest metacentric pair & & Yes $^{\text {a }}$ & Present study \\
\hline
\end{tabular}


Table 1. Cont.

\begin{tabular}{|c|c|c|c|c|c|}
\hline Ant species & $2 n /(n)$ & $\begin{array}{c}\text { Localization of rDNA genes } \\
\text { in karyotype }\end{array}$ & Ideogram & $\begin{array}{c}\text { Co-localization } \\
\text { CMA3/rDNA }\end{array}$ & $\begin{array}{c}\text { Reference } \\
\mathrm{CMA}_{3} / \mathrm{rDNA}\end{array}$ \\
\hline \multicolumn{6}{|l|}{ Subfamily Ectatomminae } \\
\hline Gnamptogenys moelleri & 34,44 & 4th metacentric pair & & Yes & Teixeira et al. (2020) \\
\hline Gnamptongeys regularis ${ }^{\mathrm{d}}$ & 26 & $\begin{array}{c}\text { Metacentric and } \\
\text { submetacentric homologous }\end{array}$ & & Yes & Teixeira et al. (2020) \\
\hline Gnamptogenys striatula & 32 & 5th metacentric pair & & Yes & Teixeira et al. (2020) \\
\hline Gnamptogenys striatula & 34 & 4th metacentric pair & & Yes & Teixeira et al. (2020) \\
\hline Gnamptogenys triangularis & 24 & Largest metacentric pair & & Yes & Teixeira et al. (2020) \\
\hline Gnamptogenys tortuolosa ${ }^{\mathrm{c}}$ & 44 & $\begin{array}{c}\text { Subtelocentric and } \\
\text { submetacentric homologous }\end{array}$ & & Yes & Present study \\
\hline \multicolumn{6}{|l|}{ Subfamily Dolichoderinae } \\
\hline Dolichoderus attelaboides & 58 & Largest submetacentric pair & & Yes & Santos et al. (2016) \\
\hline Dolichoderus bidens & 18 & Largest metacentric pair & & Yes $^{\text {a }}$ & Santos et al. (2016) \\
\hline Dolichoderus decollatus & 38 & 2nd metacentric pair & & Yes & Santos et al. (2016) \\
\hline Dolichoderus diversus & 22 & Largest metacentric pair & & Yes $^{\mathrm{a}}$ & Santos et al. (2016) \\
\hline
\end{tabular}


Table 1. Cont.

\begin{tabular}{cccccc}
\hline Ant species & 2n/(n) & $\begin{array}{c}\text { Localization of rDNA genes } \\
\text { in karyotype }\end{array}$ & Ideogram & $\begin{array}{c}\text { Co-localization } \\
\text { CMA3/rDNA }\end{array}$ & $\begin{array}{c}\text { Reference } \\
\text { CMA3/rDNA }\end{array}$ \\
\hline Dolichoderus imitator & 38 & Largest metacentric pair & Yes & Santos et al. (2016) \\
Dolichoderus lutosus & 10 & 2nd metacentric pair & Yes $^{\text {a }}$ & Santos et al. (2016) \\
Dolichoderus voraginosus & 20 & Largest metacentric pair & No $^{\text {a }}$ & Santos et al. (2016) \\
\hline
\end{tabular}

\section{Australian ants}

\section{Subfamily Myrmeciinae}

$\begin{array}{ccc}\text { Myrmecia banksi }^{\text {c }} & 10 & \text { Smallest acrocentric parr } \\ \text { Myrmecia chasei } & 47 & \text { Multiple pairs } \\ \text { Myrmecia croslandi }^{\mathrm{d}} & 2,3,4^{\mathrm{b}} & \text { Acrocentric pair } \\ \text { Myrmecia forficata } & 52^{\mathrm{b}}, 54 & \text { Multiple pairs } \\ \text { Myrmecia fulvipes } & 48,50 & \text { Multiple pairs } \\ \text { Myrmecia gulosa } & 38^{\mathrm{b}} & \text { Multiple pairs } \\ \text { Myrmecia haskinsorum } & 18 & \text { Multiple pairs }\end{array}$

D

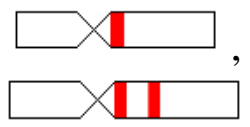

-

$-$

$-$

-
Hirai et al. (1994), (1996)

Hirai et al. (1996)

Hirai et al. (1994), (1996)

Hirai et al. (1996)

Hirai et al. (1996)

Hirai et al. (1996)

Hirai et al. (1994), (1996) 
Table 1. Cont.

\begin{tabular}{|c|c|c|c|c|c|}
\hline Ant species & $2 n /(n)$ & $\begin{array}{l}\text { Localization of rDNA genes } \\
\text { in karyotype }\end{array}$ & Ideogram & $\begin{array}{c}\text { Co-localization } \\
\text { CMA3/rDNA }\end{array}$ & $\begin{array}{c}\text { Reference } \\
\text { CMA }_{3} / \text { rDNA }\end{array}$ \\
\hline Myrmecia imaii ${ }^{\mathrm{c}}$ & 8 & Largest acrocentric pair & & - & $\begin{array}{l}\text { Hirai et al. (1994), } \\
\text { (1996) }\end{array}$ \\
\hline Myrmecia mandibularis & $56^{\mathrm{b}}$ & Multiple pairs & - & - & Hirai et al. (1996) \\
\hline Myrmecia michaelseni & 27 & Multiple pairs & - & - & Hirai et al. (1996) \\
\hline Myrmecia occidentalis & $64^{\mathrm{b}}$ & Multiple pairs & - & - & Hirai et al. (1996) \\
\hline Myrmecia pavida & 44 & Multiple pairs & - & - & Hirai et al. 1996 \\
\hline Myrmecia pilosula & $22^{b}$ & Acrocentric pair & C & - & Hirai et al. (1996) \\
\hline Myrmecia pilosula & $19,23^{b}, 27,32$ & Multiple pairs & - & - & $\begin{array}{l}\text { Hirai et al. (1994), } \\
\text { (1996) }\end{array}$ \\
\hline Myrmecia simillima & $70^{\mathrm{b}}$ & Multiple pairs & - & - & Hirai et al. (1996) \\
\hline Myrmecia arnoldi & $\begin{array}{c}53,55,57,59 \\
60^{\mathrm{b}}, 64,66\end{array}$ & Multiple pairs & - & - & Hirai et al. (1996) \\
\hline Myrmecia vindex & 74,76 & Multiple pairs & - & - & Hirai et al. (1996) \\
\hline
\end{tabular}

Palearctic ant

\section{Subfamily Dolichoderinae}

Tapinoma nigerrimum $18 \quad$ Largest submetacentric pair $\quad \square \quad \square$ Lorite et al. (1997)

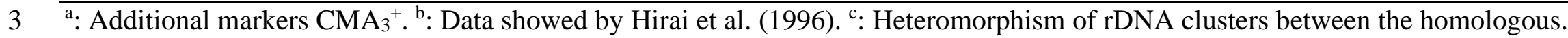

4 d. Polymorphism of rDNA clusters between the homologous. - unavailable data. 
Table 2. The relationship between Neotropical ant species studied using $18 \mathrm{~S}$ rDNA FISH and their chromosome number

\begin{tabular}{|c|c|c|c|c|}
\hline Ant species & Subfamily & Locality & $2 n$ & 3 \\
\hline Acromyrmex echinatior (Forel, 1899) & Myrmicinae & Barro Colorado - Panamá & 38 & 4 \\
\hline Anochetus targionii Emery 1894 & Ponerinae & Campus Agronomique, Kourou - FG & 30 & 5 \\
\hline Camponotus atriceps (Smith, 1858) & Formicinae & Viçosa - Minas Gerais - BR & 40 & 6 \\
\hline Crematogaster longispina Emery, 1890 & Myrmicinae & La Montagne des Singes - FG & 24 & 7 \\
\hline Gigantiops destructor (Fabricius, 1804) & Formicinae & Sinnamary - FG & 78 & $\begin{array}{l}0 \\
9\end{array}$ \\
\hline Gnamptogenys tortuolosa (Smith, 1858) & Ectatominae & Sinnamary - FG & 44 & 10 \\
\hline Myrmicocrypta sp. & Myrmicinae & Sinnamary - FG & 30 & 11 \\
\hline Odontomachus bauri Emery, 1892 & Ponerinae & Açailândia - Maranhão - BR & 44 & 12 \\
\hline Odontomachus haematodus (Linnaeus, 1758) & Ponerinae & $\begin{array}{c}\text { Campus Agronomique, Kourou - FG } \\
\text { Ubá - Minas Gerais - BR }\end{array}$ & 44 & $\begin{array}{l}13 \\
14\end{array}$ \\
\hline Pheidole germaini Emery, 1896 & Myrmicinae & Viçosa - Minas Gerais - BR & 22 & 15 \\
\hline Pseudoponera gilberti (Kempf, 1960) & Ponerinae & Sinnamary - FG & 12 & 16 \\
\hline Solenopsis geminata (Fabricius, 1804) & Myrmicinae & Sinnamary - FG & 32 & $\begin{array}{l}17 \\
18\end{array}$ \\
\hline Strumigenys diabola Bolton 2000 & Myrmicinae & Sinnamary - FG & 40 & 19 \\
\hline
\end{tabular}

21 FG: French Guiana, BR: Brazil. 
Size variations in the rDNA clusters can be observed when these genes are located

2 in the interstitial/pericentromeric region of the chromosomes, as seen in Gnamptogenys

3 regularis Mayr, 1870 (Teixeira et al., 2020) and in O. bauri (this study). A different path

4 seems to be involved in the evolution of these karyotypes compared to the rearrangements

5 involved in terminal rDNA heteromorphisms. In these cases, the mechanism may be

6 associated with the formation of extrachromosomal circular DNA (eccDNA), which is

7 likely to form tandem repetitive sequences similar to the rDNA genes (Cohen and Segal,

8 2009). These eccDNAs may be lost, leading to deletions in the original rDNA sequences,

9 or they may be replicated via a rolling circle mechanism and reintegrated into the original

10 chromosome, producing duplications of these repetitive sequences (Cohen and Segal,

11 2009).

12 In ants as well as in other eukaryotes, rDNA clusters are located in GC-rich

13 regions (Symonová, 2019) and, therefore, usually coincide with $\mathrm{CMA}_{3}{ }^{+}$bands, possibly

14 as a result of GC-biased gene conversion ( $\mathrm{gBGC}$ ) over the course of evolutionary time

15 (Escobar et al., 2011). This co-localization of GC-rich regions and rDNA was observed

16 for all the ants studied to date (Table 2), with the exception of D. voraginosus (Santos et

$17 a l ., 2016)$. However, GC-rich chromatin is not always an indication of ribosomal genes,

18 as seen here in $G$. destructor, $P$. gilberti, and in some Dolichoderus spp. and fungus-

19 farming ants (Table 2).

20 In insects, a compilation of previous data concerning rDNA genes has been

21 conducted, for example, in moths and butterflies (Lepidoptera; Nguyen et al., 2010),

22 beetles (Coleoptera; Dutrillaux and Dutrillaux, 2012), and kissing bugs (Heteroptera;

23 Panzera et al., 2012). However, this is the first survey of Hymenoptera species. We have

24 compiled available information and new data on 13 Neotropical ant species. In different

25 organisms, including ants, the number and location of chromosomes bearing rDNA 
1 clusters within the genome follow general patterns that govern the modes of evolution for

2 these genes (Martins and Wasko, 2004; Nguyen et al., 2010; Dutrillaux et al., 2016;

3 Gerbault-Seureau et al., 2017; Hirai, 2020; this study). We can conclude that having only

4 a single pair of chromosomes bearing rDNA clusters is more common in the ant genome

5 because of the pericentromeric/interstitial location of these genes on the chromosomes.

6 Intrachromosomal regions are sites with low frequencies of rearrangements, such as non-

7 Robertsonian translocations and ectopic recombination, and are therefore less prone to

8 meiotic abnormalities. It should be assumed that the chromosomal location of rDNA

9 clusters influences the dispersion of these genes within the karyotype.

10 Future studies will allow the mapping of rDNA genes in more ant taxa, including 11 the other remaining subfamilies. Other repetitive sequences, such as $5 \mathrm{~S} \mathrm{rDNA}$ and histone 12 genes, may also be mapped in ant species as a tool to investigate further patterns that 13 reflect the relationship between chromosomal location and dispersion in the genome.

14 Finally, a solid understanding of the evolutionary patterns of ribosomal gene dispersal in 15 ant chromosomes may provide a comparative model for other insects.

\section{Experimental Procedures}

\section{1 - Obtaining samples for analysis}

Field surveys to collect ant colonies were performed in French Guiana, Brazil, and

22 Panama (Table 1) from the following locations: La Montagne des Singes, Kourou

23 (5.07225, -52.69407), Campus Agronomique, Kourou (5.17312, -52.65480), and

24 Sinnamary $(5.28482,-52.91403)$, all in French Guiana; Viçosa (-20.757041, -42.873516) 
1 and Ubá (-21.128880, -42.937646), both in Minas Gerais, Brazil, and Açailândia (2 4.84200, -47.29667) in Maranhão, Brazil; and Barro Colorado Island (9.150000, -

3 79.83333) in Panama. Sampling permit in Brazil was provided by the Instituto Chico

4 Mendes de Conservação da Biodiversidade (ICMBio) (SISBIO accession numbers 32459

5 and 62598). Adult specimens were identified by Dr. Jacques H. C. Delabie and deposited

6 in the ant collection at the Laboratório de Mirmecologia do Centro de Pesquisas do Cacau

7 (CPDC/Brazil), in Bahia, Brazil, under records \#5802, \#5803, and \#5804.

In this study, previous molecular cytogenetic data related to rDNA genes (45S,

$918 \mathrm{~S}$, or 28S) mapped by FISH from 50 ant species were used. For comparative analysis,

10 the following traits were considered for each species: chromosome number, number of 11 rDNA-bearing chromosomes, location of rDNA clusters in the karyotype, and co-

12 localization of $\mathrm{CMA}_{3}$ fluorochrome and rDNA clusters. Ag-NOR data were disregarded

13 due to the highly variable patterns and unreliable results (for details, see Introduction).

2 - Chromosome preparation

Mitotic metaphase chromosomes were obtained from the cerebral ganglia of larvae after meconium elimination, using colchicine hypotonic solution $(0,005 \%)$ and 19 fixatives according to the methods described by Imai et al. (1988).

3 - Staining with fluorochromes chromomycin $\mathrm{A}_{3}$ (CMA3) and 4'6- diamidino-2phenylindole (DAPI) with the fluorochromes $\mathrm{CMA}_{3}$ and DAPI for the detection of GC and AT-rich regions, 
1 respectively, based on the technique proposed by Schweizer (1980). The Ac. echinatior

2 samples studied here correspond to the same colonies studied by Barros et al. (2016) and

3 the $\mathrm{CMA}_{3} / \mathrm{DAPI}$ staining in this species was performed by these authors.

\section{4 - Fluorescent in situ hybridization with rDNA $18 S$ probe}

6

The $18 \mathrm{~S}$ rDNA probes were obtained by amplification via polymerase chain reaction (PCR) using Melipona quiquefasciata Lepeletier, 1836, rDNA primers 18SF1 (5'-GTC ATA GCT TTG TCT CAA AGA-3') and 18SR1.1 (5'-CGC AAA TGA AAC TTT AAT CT-3') (Pereira, 2006) in the genomic DNA from the ant Camponotus rufipes (Fabricius, 1775). Gene amplification was performed following Pereira (2006). The probes were labeled by an indirect method using digoxigenin-11-dUTP (Roche Applied Science, Mannheim, Germany), and the FISH signals were detected with antidigoxigenin-rhodamine (Roche Applied Science), following the manufacturer's protocol. The rDNA 18 S genes were mapped by FISH, following the protocol of Pinkel et al. (1986). The slides were treated with RNase A $(100 \mu \mathrm{g} / \mathrm{mL})$ and kept in a moist chamber at $37^{\circ} \mathrm{C}$ for $1 \mathrm{~h}$. After that, they were washed in $2 \times \mathrm{SSC}$ for $5 \mathrm{~min}$, incubated in $5 \mu \mathrm{g} / \mathrm{ml}$ pepsin in $0.01 \mathrm{~N} \mathrm{HCl}$ for $10 \mathrm{~min}$, washed in $1 \times \mathrm{PBS}$ for $5 \mathrm{~min}$ and dehydrated in $50 \%, 70 \%$ and $100 \%$ alcohol series for 2 min each. After this pretreatment, metaphase chromosomes were denatured in $70 \%$ formamide $/ 2 \times \mathrm{SSC}$ at $75^{\circ} \mathrm{C}$ for $3 \mathrm{~min}$, and $20 \mu \mathrm{L}$ of hybridization mix including $200 \mathrm{ng}$ of labeled probe, $2 \times \mathrm{SSC}, 50 \%$ formamide, and $10 \%$ dextran sulfate was denatured for $10 \mathrm{~min}$ at $85^{\circ} \mathrm{C}$ and added on preparations. The slides were kept in a moist chamber at $37^{\circ} \mathrm{C}$ overnight. Then, the slides were washed in $2 \times \mathrm{SSC}$ for $5 \mathrm{~min}$; the detection solution including anti-digoxigenin-rhodamine was added on slides that were kept in a moist chamber at $37^{\circ} \mathrm{C}$ for $1 \mathrm{~h}$. The slides were washed in 
$14 \times \mathrm{SSC} / \mathrm{Tween}$, and dehydrated in an alcohol series. Finally, counterstaining with DAPI

2 (DAPI Fluoroshield, Sigma Aldrich) was performed.

3

45 - Chromosomal analysis

Chromosomes were arranged in order of decreasing size and based on the ratio of

7 the chromosomes arm lengths ( $\mathrm{r}=$ long arm/short arm), according to the classification

8 proposed by Levan et al. (1964). The chromosomes were classified as $\mathrm{m}=$ metacentric ( $\mathrm{r}$

$9=1-1.7), \mathrm{sm}=$ submetacentric $(\mathrm{r}=1.7-3)$, st $=$ subtelocentric $(\mathrm{r}=3-7)$, and $\mathrm{a}=$

10 acrocentric $(r>7)$; they were organized using Adobe Photoshop ${ }^{\circledR}$ 21.1.1 and measured

11 using Image Pro Plus®. Ideograms of the NOR-bearing chromosome/chromosomes (i.e.,

12 graphical representation of the chromosomes concerning the rDNA clusters) of the ant

13 species were then designed with the Easy Idio software (Diniz and Xavier, 2006).

14 For the fluorochrome staining and FISH 18S rDNA technique, 30 metaphases

15 from at least three individuals of each species were analyzed. In the case of $O$. bauri,

16 which presented a chromosomal polymorphism involving rDNA clusters, seven

17 individuals were analyzed (six females and one male). The metaphases were analyzed

18 and photographed using a fluorescence microscope, Olympus BX60, attached to an image

19 system, QColor Olympus ${ }^{\circledR}$, with the filters WB (450-480 nm), WU (330-385 nm), and

20 WG $(510-550 \mathrm{~nm})$ for the fluorochromes $\mathrm{CMA}_{3}$, DAPI, and rhodamine, respectively.

226 - Phylogenetic relationships

The phylogenetic relationship among ant species was determined by associating

25 with previously published molecular phylogenies. The resultant cladogram topology at 
1 the subfamily level was determined following Moreau and Bell (2013). The Poneroid

2 clade topology was determined according to Schmidt (2013) and Larabee et al. (2016);

3 the clade topology for the subfamily Dolichoderinae was determined according to Santos

4 et al. (2016) and that for the subfamily Myrmicinae was determined according to Bacci

5 et al. (2009), Ward et al. (2015), Queiroz (2015), Solomon et al. (2019), and Micolino et

6 al. (2019a). The topology of the species groups within the subfamily Myrmeciinae was

7 determined according to Hasegawa and Crozier (2006).

8

9 Acknowledgments

10

11 We would like to thank Dr. Cléa S. F. Mariano for kindly providing Acromyrmex

12 echinatior samples, Dr. Jacques H. C. Delabie for species identification, and Dr. Luiz

13 Fernando Gomes for his valuable assistance in the laboratory with Odontomachus bauri

14 chromosome preparations. We also acknowledge Laboratório de Biologia Molecular de

15 Insetos of the Universidade Federal de Viçosa (UFV) for technical support. GAT thanks

16 the Conselho Nacional de Desenvolvimento Científico e Tecnológico (CNPq) and

17 Coordenação de Aperfeiçoamento de Pessoal de Nível Superior (CAPES) for the

18 scholarships granted. Financial support for this study was provided by "Investissement

19 d'Avenir" grants managed by the French Agence Nationale de la Recherche (DRIIHM

20 ref. ANR-11-LABX-0010 and CEBA, ref. ANR-10-LABX-25-01), by the PO-FEDER

21 2014-2020, Région Guyane (BiNG, ref. GY0007194), and by the Programa de Auxílio

22 ao Pesquisador - PAPESQ/UNIFAP/2019. 

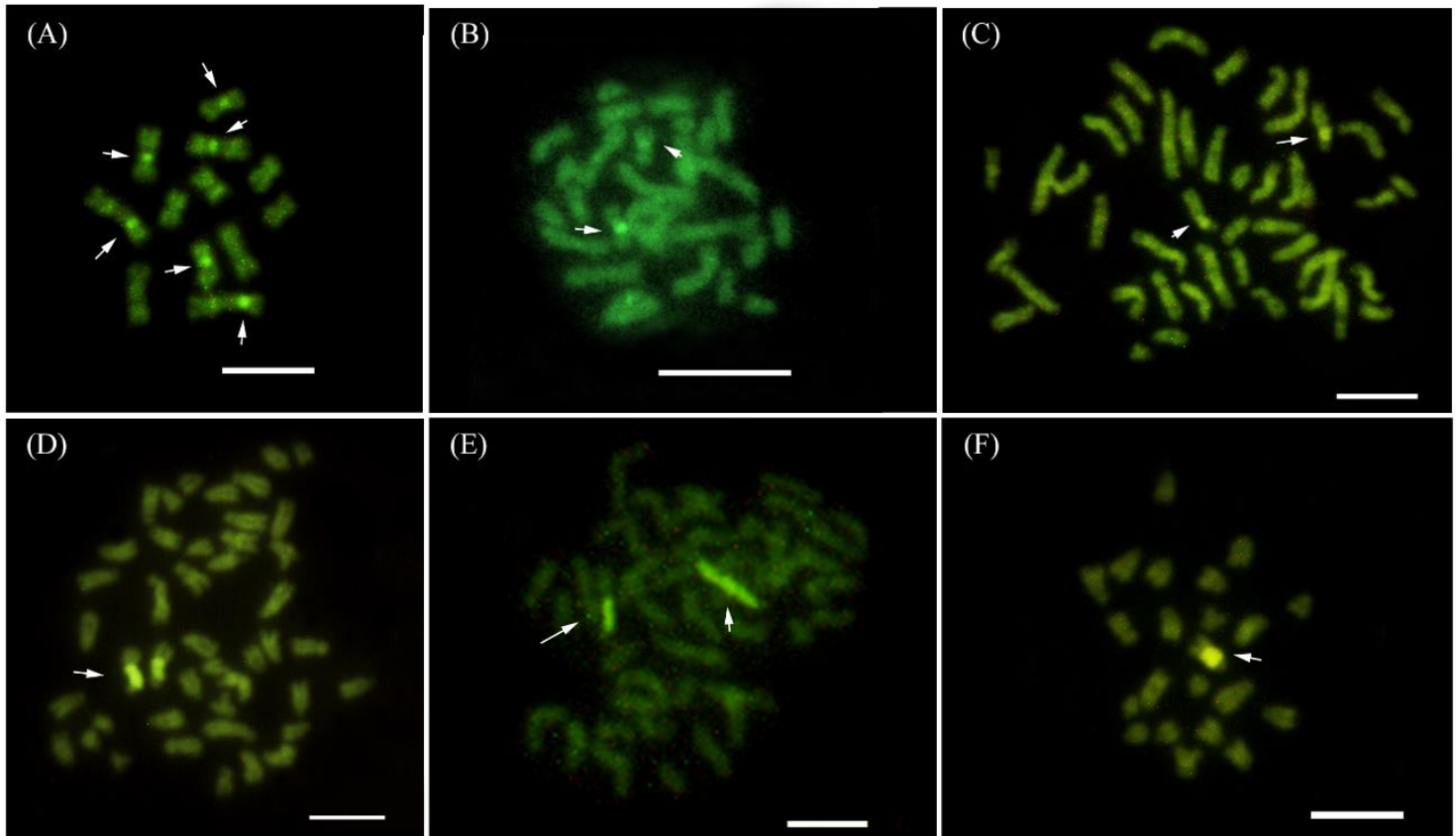

(E)

(F)
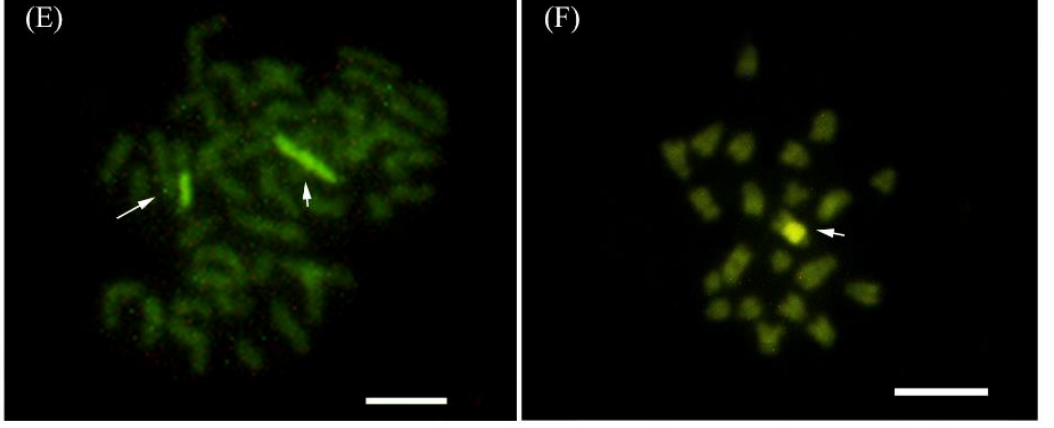

2 Figure S1. Staining with chromomycin $\mathrm{A}_{3}$ showing GC-rich regions (arrows) of

3 Ponerinae ants: (A) Pseudoponera gilberti (2n=12), (B) Anochetus targionii (2n=30), (C)

4 Odontomachus haematodus (2n=44, French Guiana), (D, E) Odontomachus bauri

5 showing the homozygous and heterozygous states, respectively $(2 n=44)$, and (F) male of

6 Odontomachus bauri with the smaller size regions rich in GC base pairs. Bars $=5 \mu \mathrm{m}$. 

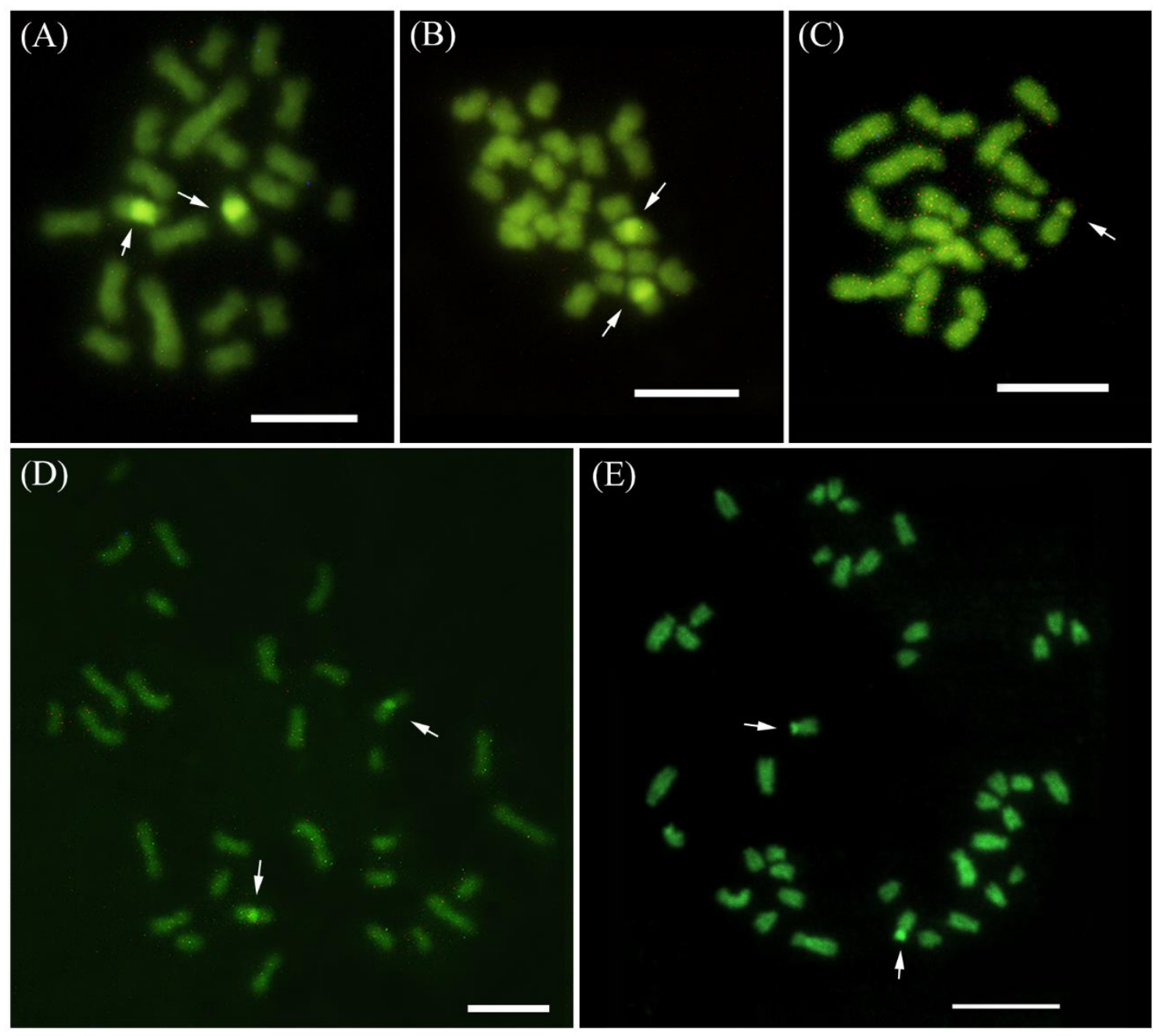

2 Figure S2. Staining with chromomycin $\mathrm{A}_{3}$ showing GC-rich regions (arrows) of

3 Myrmicinae ants: (A) Pheidole germaini (2n=22), (B) Crematogaster longispina

$4 \quad(2 \mathrm{n}=24),(\mathrm{C})$ Solenopsis geminata $(\mathrm{n}=16),(\mathrm{D})$ Myrmicocrypta sp. $(2 \mathrm{n}=30)$, (E)

$5 \quad$ Strumigenys diabola $(2 \mathrm{n}=40)$. Bars $=5 \mu \mathrm{m}$. 

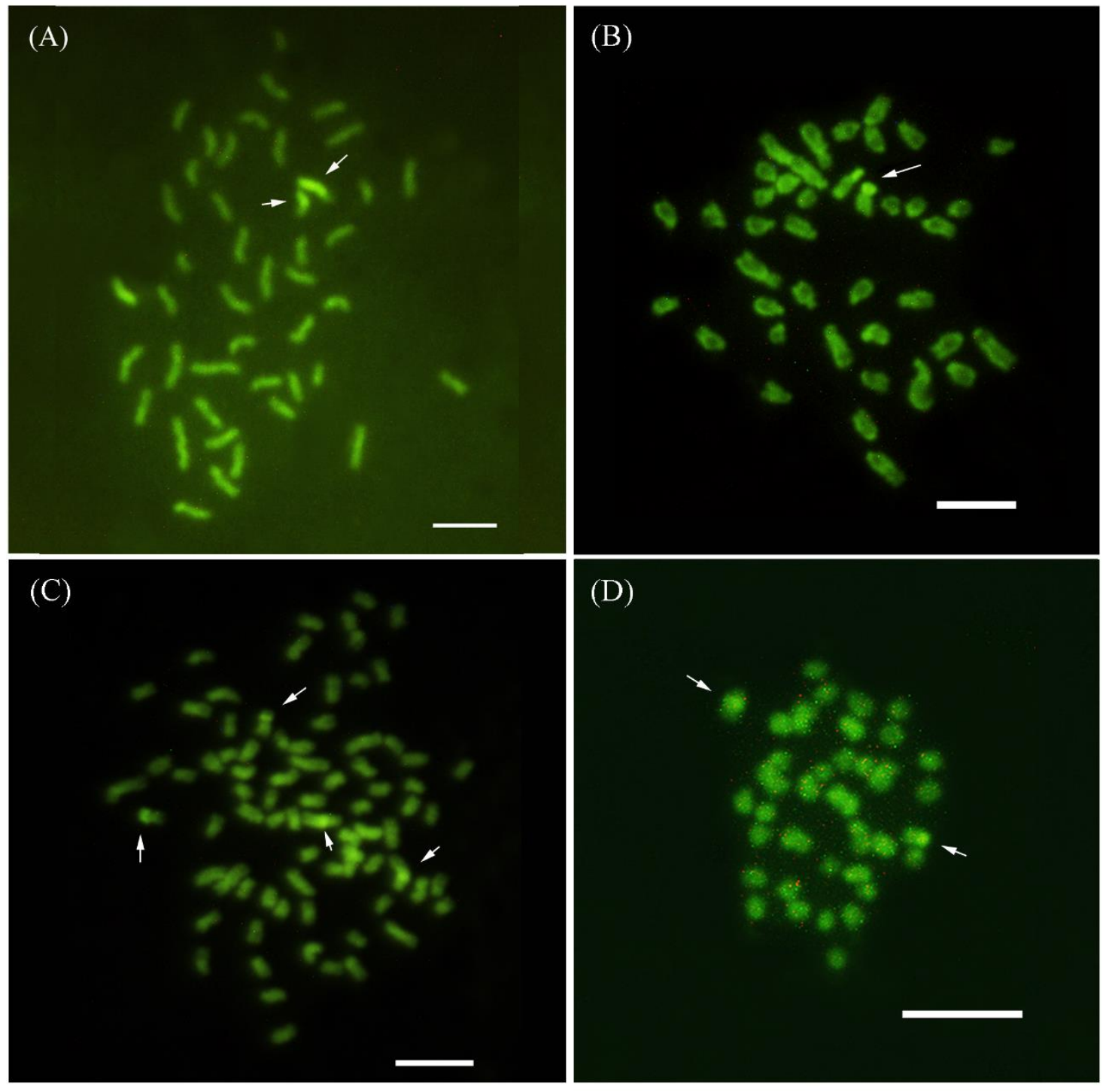

2 Figure $\mathbf{S 3}$ Staining with chromomycin $\mathrm{A}_{3}$ showing GC-rich regions (arrows) of an

3 Ectatomminae ant (A) Gnamptogenys tortuolosa $(2 \mathrm{n}=44)$, and Formicinae ants (B)

4 Camponotus atriceps $(2 \mathrm{n}=40)$ and $(\mathrm{C}, \mathrm{D})$ Gigantiops destructor $(2 \mathrm{n}=78, \mathrm{n}=39)$. Bars $=5$

$5 \mu \mathrm{m}$. 


\section{$1 \quad$ References}

2

3 Aguiar, H.J.A.C., Barros, L.A.C., Alves, D.R., Mariano, C.S.F., Delabie, J.H.C. and

4 Pompolo, S.G. (2017) Cytogenetic studies on populations of Camponotus rufipes

5 (Fabricius, 1775) and Camponotus renggeri Emery, 1894 (Formicidae: Formicinae).

$6 \quad P L O S$ ONE, 12(5), e0177702.

7 Aguiar, H.J.A.C., Barros, L.A.C., Mariano, C.S.F., Delabie, J.H.C. and Pompolo, S.G.

8 (2011) 45S rDNA localization for the giant Ant Dinoponera gigantea with Evolutionary

9 inferences for the Dinoponera Genus (Formicidae: Ponerinae). Sociobiology, 57(3),

$10 \quad 607-620$.

11 Andrade-Souza, V., Duarte, O.M.P., Martins, C.C.C., Santos, I.S., Costa, M.G.C. and

12 Costa, M.A. (2018) Comparative molecular cytogenetics of Melipona Illiger species

13 (Hymenoptera: Apidae). Sociobiology, 65(4), 696-705.

14 Bacci, Jr. M., Solomon, S.E., Mueller, U.G., Martins, V.G., Carvalho, A.O.R., Vieira,

15 L.G.E. and Silva-Pinhati, A.C.O. (2009). Phylogeny of leafcutter ants in the genus Atta

16 Fabricius (Formicidae: Attini) based on mitochondrial and nuclear DNA sequences.

17 Molecular Phylogenetics and Evolution, 51(3), 427-437.

18 Barbosa, P., Leal, E.V., Silva, M., Almeida, M.C., Moreira-Filho, O. and Artoni, R.F.

19 (2017). Variability and evolutionary implications of repetitive DNA dynamics in

20 genome of Astyanax scabripinnis (Teleostei, Characidae). Comparative Cytogenetics,

$21 \quad \mathbf{1 1}(1), 143-162$.

22 Barros, L.A.C., Aguiar, H.J.A.C., Andrade-Souza, V., Mariano, C.S.F., Delabie, J.H.C.

23 and Pompolo, S.G. (2012). Occurrence of pre-nucleolar bodies and 45S rDNA location 
1 on the chromosomes of the ant Mycocepurus goeldii (Forel) (Formicidae, Myrmicinae,

2 Attini). Hereditas, 149, 50-54.

3 Barros, L.A.C., Aguiar, H.J.A.C., Mariano, C.S., Andrade-Souza, V., Costa, M.A.,

4 Delabie, J.H.C. and Pompolo, S.G. (2016). Cytogenetic data on six leafcutter ants of the

5 genus Acromyrmex Mayr, 1865 (Hymenoptera, Formicidae, Myrmicinae): insights into

6 chromosome evolution and taxonomic implications. Comparative Cytogenetics, 10(2),

$7 \quad 229-243$.

8 Barros, L.A.C., Aguiar, H.J.A.C., Mariano, C.S.F., Delabie, J.H.C. and Pompolo, S.G.

9 (2010). Cytogenetic characterization of the lower-Attine Mycocepurus goeldii

10 (Formicidae: Myrmicinae: Attini). Sociobiology, 56, 57-66.

11 Barros, L.A.C., Aguiar, H.J.A.C., Teixeira, G.A., Mariano, C.S.F., Teixeira, M.C.,

12 Delabie, J.H.C. and Pompolo, S.G. (2015). Cytogenetic data on the threatened leafcutter

13 ant Atta robusta Borgmeier, 1939 (Formicidae: Myrmicinae: Attini). Comptes Rendus

14 Biologies, 338(10), 660-665.

15 Barros, L.A.C., Mariano, C.S.F., Pompolo, S.G., and Delabie, J.H.C. (2009). Hsc-FA

16 and NOR bandings on chromosomes of the giant ant Dinoponera lucida Emery, 1901

17 (Hymenoptera: Formicidae). Comparative Cytogenetics, 3, 97-102.

18 Barros, L.A.C., Teixeira, G.A., Aguiar, H.J.A.C., Lopes, D.M. and Pompolo, S.G.

19 (2018). Cytogenetic studies in Trachymyrmex holmgreni Wheeler, 1925 (Formicidae:

20 Myrmicinae) by conventional and molecular methods. Sociobiology, 65(2), 185-190.

21 Barros, L.A.C., Teixeira, G.A., Aguiar, H.J.A.C., Mariano, C.S.F, Delabie, J.H.C. and

22 Pompolo, S.G. (2014). Banding patterns of three leafcutter ant species of the genus Atta

23 (Formicidae: Myrmicinae) and Chromosomal Inferences. Florida Entomologist, 97(4),

$24 \quad 1694-1701$. 
1 Bolton, B. 2020. An online catalog of the ants of the world. Available from

2 https://antcat.org. (accessed $15^{\text {th }}$ May, 2020)

3 Britton-Davidian, J., Cazaux, B. and Catalan, J. (2012). Chromosomal dynamics of

4 nucleolar organizer regions (NORs) in the house mouse: micro-evolutionary insights.

5 Heredity, 108(1), 68-74.

6 Cabral-de-Mello, D.C., Oliveira, S.G., Moura, R.C. and Martins, C. (2011).

7 Chromosomal organization of the 18S and 5S rRNAs and histone $\mathrm{H} 3$ genes in

8 Scarabaeinae coleopterans: insights into the evolutionary dynamics of multigene

9 families and heterochromatin. BMC Genetics, 12, 88.

10 Cardoso, D.C., Pompolo, S.G., Cristiano, M.P. and Tavares, M.G. (2014). The role of

11 fusion in ant chromosome evolution: insights from cytogenetic analysis using a

12 molecular phylogenetic approach in the genus Mycetophylax. PLoS ONE, 9(4), e95408.

13 Castro, C.P.M., Cardoso, D.C., Micolino, R., and Cristiano, M.P. (2020). Comparative

14 FISH-mapping of TTAGG telomeric sequences to the chromosomes of leafcutter ants

15 (Formicidae, Myrmicinae): is the insect canonical sequence conserved? Comparative

16 Cytogenetics, 14(3), 369-385.

17 Cazaux, B., Catalan, J., Veyrunes, F., Douzery, E.J. and Britton-Davidian, J. (2011).

18 Are ribosomal DNA clusters rearrangement hotspots? A case study in the genus Mus

19 (Rodentia, Muridae). BMC Evolutionary Biology, 11(1), 124.

20 Cholak, L.R., Haddad, C.F. and Parise-Maltempi, P.P. (2020). Cytogenetic analysis of

21 the genus Thoropa Cope, 1865 (Anura-Cycloramphidae) with evolutionary inferences

22 based on repetitive sequences. Genetics and Molecular Biology, 43(3). 
1 Cohen, S. and Segal, D. (2009). Extrachromosomal Circular DNA in Eukaryotes:

2 possible involvement in the plasticity of tandem repeats. Cytogenetic and Genome

3 Research, 124, 327-338.

4 Cristiano, M.P., Cardoso, D.C. and Fernandes-Salomão, T.M. (2013). Cytogenetic and

5 molecular analyses reveal a divergence between Acromyrmex striatus (Roger, 1863) and

6 other congeneric species: taxonomic implications. PLOS ONE, 8(3), e59784.

7 Cross, I., Vega, L., and Rebordinos, L. (2003). Nucleolar organizing regions in

8 Crassostrea angulata: chromosomal location and polymorphism. Genetica, 119(1), 65-

974

10 Degrandi, T.M., Gunski, R.J., Garnero, A.D.V., Oliveira, E.H.C.D., Kretschmer, R.,

11 Souza, M.S.D., Barcellos S.A. and Hass, I. (2020). The distribution of 45S rDNA sites

12 in bird chromosomes suggests multiple evolutionary histories. Genetics and Molecular

13 Biology, 43(2).

14 Diniz, D. and Xavier, P.M. (2006). Easy Idio.

15 Dobigny, G., Ozouf-Costaz, C., Bonillo, C. and Volobouev, V. (2002). "Ag-NORs" are

16 not always true NORs: new evidence in mammals. Cytogenetic and Genome Research,

$17 \quad 98(1), 75-77$.

18 Dutra, R.T., Bitencourt, J., Netto, M.R.C.B., Paim, F.G., Sarmento-Soares. L.M. and

19 Afonso, P.R.A.M. (2020). Chromosomal markers are useful to species identification in

20 Rivulidae (Cyprinodontiformes, Aplocheiloidei), including the resolution of taxonomic

21 uncertainties in a vulnerable species complex. Zebrafish, 17(1), 48-55.

22 Dutrillaux, A.M. and Dutrillaux, B. (2012). Chromosome analysis of 82 species of

23 Scarabaeoidea (Coleoptera), with special focus on NOR localization. Cytogenetic and

24 Genome Research, 136(3), 208-219. 
1 Dutrillaux, A.M., Carton, B., Cacheux, L and Dutrillaux, B. (2016). Interstitial NORs,

2 fragile sites, and chromosome evolution: a not so simple relationship-the example of

3 Melolontha melolontha and genus Protaetia (Coleoptera: Scarabaeidae). Cytogenetic

4 and Genome Research, 149(4), 304-311.

5 Escobar, J.S., Glémin, S. and Galtier, N. (2011). GC-biased gene conversion impacts

6 ribosomal DNA evolution in vertebrates, angiosperms, and other eukaryotes. Molecular

7 Biology and Evolution, 28(9), 2561-2575.

8 Falcione, C., Hernando, A. and Bressa, M.J. (2018). Comparative cytogenetic analysis

9 in Erythrolamprus snakes (Serpentes: Dipsadidae) from Argentina. Anais da Academia

10 Brasileira de Ciências, 90(2), 1417-1429.

11 Ferreti, A.B.S.M., Ruiz-Ruano, F.J., Milani, D., Loreto, V., Martí, D.A., Ramos, E.,

12 Martins, C. and Cabral-de-Mello, D.C. (2019). How dynamic could be the 45S rDNA

13 cistron? An intriguing variability in a grasshopper species revealed by integration of

14 chromosomal and genomic data. Chromosoma, 128, 165-175.

15 Gerbault-Seureau, M., Cacheux, L. and Dutrillaux, B. (2017). The relationship between

16 the (In-) stability of NORs and their chromosomal location: the example of

17 Cercopithecidae and a short review of other primates. Cytogenetic and Genome

18 Research, 153(3), 138-146.

19 Gokhman, V.E., Anokhin, B.A. and Kuznetsova, V.G. (2014). Distribution of 18S

20 rDNA sites and absence of the canonical TTAGG insect telomeric repeat in parasitoid

21 Hymenoptera. Genetica, 142, 317-322.

22 Gokhman, V.E., Bolsheva, N.L., Govind, S. and Muravenko, O.V. (2016). A

23 comparative cytogenetic study of Drosophila parasitoids (Hymenoptera, Figitidae) 
1 using DNA-binding fluorochromes and FISH with 45S rDNA probe. Genetica, 144(3),

$2 \quad 335-339$.

3 Golub, N.V., Golub, V.B. and Kuznetsova, V.G. (2015). Variability of 18rDNA loci in

4 four lace bug species (Hemiptera, Tingidae) with the same chromosome number.

5 Comparative Cytogenetics, 9(4), 513-522.

6 Gross, M.C., Schneider, C.H., Valente, G.T., Martins, C. and Feldberg E. (2010).

$7 \quad$ Variability of $18 \mathrm{~S}$ rDNA locus among Symphysodon fishes: chromosomal

8 rearrangements. Journal of Fish Biologies, 76(5), 1117-1127.

9 Hasegawa, E, and Crozier, R.H. (2006). Phylogenetic relationships among species

10 groups of the ant genus Myrmecia. Molecular Phylogenetics and Evolution, 38, 575-

11582.

12 Hirai, H. (2020). Chromosome dynamics regulating genomic dispersion and alteration

13 of Nucleolus Organizer Regions (NORs). Cells, 9(4), 971-984.

14 Hirai, H., Yamamoto, M.T., Ogura, K., Satta, Y., Yamada, M., Taylor, R.W. and Imai,

15 H.T. (1994). Multiplication of 28S rDNA and NOR activity in chromosome evolution

16 among ants of the Myrmecia pilosula species complex. Chromosoma, 103(3), 171-178.

17 Hirai, H., Yamamoto, M.T., Taylor, R.W. and Imai, H.T. (1996). Genomic dispersion of

$1828 \mathrm{~S}$ rDNA during karyotypic evolution in the ant genus Myrmecia (Formicidae).

19 Chromosoma, 105, 190-196.

20 Howell, W.T., and Black, D.A. (1980). Controlled silver-staining of nucleolus organizer

21 regions with a protective colloidal developer: a 1-step method. Experientia, 36(8), 1014-1015. 
1 Huang, Y.C., Lee, C.C., Kao, C.Y., Chang, N.C., Lin, C.C., Shoemaker, D. and Wang,

2 J. (2016). Evolution of long centromeres in fire ants. BMC Evolutionary Biology, 16,

3189.

4 Imai, H., Taylor, R.W., Crosland, M.W. and Crozier, R.H. (1988). Modes of

5 spontaneous chromosomal mutation and karyotype evolution in ants with reference to

6 the minimum interaction hypothesis. Japanese Journal of Genetics, 63, 159-185.

7 Imai, H.T., Hirai, H., Satta, Y., Shiroishi, T., Yamada, M., and Taylor, R.W. (1992).

8 Phase specific Ag-staining of nucleolar organizer regions (NORs) and kinetochores in

9 the Australian ant Myrmecia croslandi. The Japanese Journal of Genetics, 67(6), 437-

10447.

11 Imai, H.T., Taylor, R.W., and Crozier, R.H. (1994). Experimental bases for the

12 minimum interaction theory. I. Chromosome evolution in ants of the Myrmecia pilosula

13 species complex (Hymenoptera: Formicidae: Myrmeciinae). The Japanese Journal of

14 Genetics, 69(2), 137-182.

15 Larabee, F.J., Fisher, B.K., Schmidt, C.A., Matos-Maraví, P., Janda, M. and Suarez,

16 A.V. (2016). Molecular phylogenetics and diversification of trap-jaw ants in the genera

17 Anochetus and Odontomachus (Hymenoptera: Formicidae). Molecular Phylogenetics

18 and Evolution, 103, 143-154.

19 Levsky, J.F. and Singer, R.H. (2003). Fluorescence in situ hybridization: past, present

20 and future. Journal of Cell Science, 116, 2833-2838.

21 Liehr, T. (2017). "Classical cytogenetics" is not equal to "banding cytogenetics".

22 Molecular Cytogenetics, 10, 1-3.

23 Long, E.O. and Dawid, I.B. (1980). Repeated genes in eukaryotes. Annual Review of

24 Biochemistry, 49(1), 727-764. 
1 Lorite, P., and Palomeque, T. (2010). Karyotype evolution in ants (Hymenoptera:

2 Formicidae), with a review of the known ant chromosome numbers. Myrmecological

3 News, 13(1), 89-102.

4 Lorite, P., Aránega, A.E., Luque, F. and Palomeque, T. (1997). Analysis of the

5 nucleolar organizing regions in the ant Tapinoma nigerrimum (Hymenoptera,

6 Formicidae). Heredity, 78, 578-582.

7 Lorite, P., Carrillo, J.A., Tinaut, A. and Palomeque, T. (2004). Evolutionary dynamics

8 of satellite DNA in species of the genus Formica (Hymenoptera, Formicidae). Gene,

$9 \quad 332,159-168$.

10 Malimpensa, G.D.C., Traldi, J.B., Martinez, J.D.F., Deon, G., Azambuja, M., Nogaroto,

11 V., Vicari M.R. and Moreira-Filho, O. (2020). Chromosomal Diversification in Two

12 Species of Pimelodus (Siluriformes: Pimelodidae): Comparative Cytogenetic Mapping

13 of Multigene Families. Zebrafish, 17(4), 278-286.

14 Mantovani, M., Abel. L.D. and Moreira-Filho, O. (2005). Conserved 5S and variable

$1545 \mathrm{~S}$ rDNA chromosomal localization revealed by FISH in Astyanax scabripinnis

16 (Pisces, Characidae). Genetica, 123, 211-216.

17 Mariano, C.S.F., Barros, L.A.C., Velasco, Y.M., Guimarães, I.N., Pompolo, S.G. and

18 Delabie, J.H.C. (2019). Citogenética de hormigas de la región neotropical, In Hormigas

19 de Colombia (Fernández, F., Guerrero, R. and Delsinne, T., eds.). pp. 131-157.

20 Universidad Nacional de Colombia, Bogotá.

21 Mariano, C.S.F., Pompolo, S.G., Barros, L.A.C., Mariano-Neto, E., Campiolo, S. and

22 Delabie, J.C.H. (2008). A biogeographical study of the threatened ant Dinoponera

23 lucida Emery (Hymenoptera: Formicidae: Ponerinae) using a cytogenetic approach.

24 Insect Conservation and Diversity, 1(3), 161-168. 
1 Martins, C. and Wasko, A.P. (2004). Organization and evolution of 5S ribosomal DNA

2 in the fish genome. In Focus on genome research (Williams, C.R., ed.). pp. 335-363.

3 Nova Science Publishers Inc, New York.

4 Maryańska-Nadachowska, A., Anokhin, B.A., Gnezdilov, V.M. and Kuznetsova, V.G.

5 2016. Karyotype stability in the family Issidae (Hemiptera, Auchenorrhyncha) revealed

6 by chromosome techniques and FISH with telomeric (TTAGG)n and 18S rDNA probes.

7 Comparative Cytogenetics, 10(3), 347-369.

8 Mazzoleni, S., Rovatsos, M., Schillaci, O. and Dumas, F. (2018). Evolutionary insight

9 on localization of $18 \mathrm{~S}, 28 \mathrm{~S}$ rDNA genes on homologous chromosomes in Primates

10 genomes. Comparative Cytogenetics, 12(1), 27-40.

11 Menezes, R.S.T., Gazoni, T. and Costa, M.A. (2019). Cytogenetics of warrior wasps

12 (Vespidae: Synoeca) reveals intense evolutionary dynamics of ribosomal DNA clusters

13 and an unprecedented number of microchromosomes in Hymenoptera. Biological

14 Jounal of the Linnean Society, 126(4), 925-935.

15 Meyne, J., Hirai, H. and Imai, H.T. (1995). FISH analysis of the telomere sequences of

16 bulldog ants (Mymecia: Formicidae). Chromosoma, 104, 14-18.

17 Micolino, R., Cristiano, M,P., Travenzoli, N.M., Lopes, D.M. and Cardoso, D.C.

18 (2019a). Chromosomal dynamics in space and time: evolutionary history of

19 Mycetophylax ants across past climatic changes in the Brazilian Atlantic coast.

20 Scientific Reports, 9(1), 1-13.

21 Micolino, R., Cristiano, M. P. and Cardoso, D. C. (2019b). Population-based

22 cytogenetic banding analysis and phylogenetic relationships of the neotropical fungus-

23 farming ant Trachymyrmex holmgreni Wheeler, 1925. Cytogenetic and Genome

24 Research, 159(3), 151-162. 
1 Micolino, R., Cristiano, M.P., and Cardoso, D.C. (2020). Karyotype and putative

2 chromosomal inversion suggested by integration of cytogenetic and molecular data of

3 the fungus-farming ant Mycetomoellerius iheringi Emery, 1888. Comparative

4 Cytogenetics, 14(2), 197-210.

5 Moreau, C.S. and Bell, C.D. (2013). Testing the museum versus cradle tropical

6 biological diversity hypothesis: phylogeny, diversification, and ancestral biogeographic

7 range evolution of the ants. Evolution, 67-8, 2240-2257.

8 Nguyen, P., Sahara, K., Yoshido, A. and Marec, F. (2010). Evolutionary dynamics of

9 rDNA clusters on chromosomes of moths and butterflies (Lepidoptera). Genetica, 138,

$10 \quad 343-354$.

11 Panzera, F., Ferreiro, M.J., Pita, S., Calleros, L., Pérez, R., Basmadjián, Y., Guevara,

12 Y., Brenière, S.F. and Panzera, Y. (2014). Evolutionary and dispersal history of

13 Triatoma infestans, main vector of Chagas disease, by chromosomal markers. Infection,

14 Genetics and Evolution, 27, 105-113.

15 Panzera, Y.1., Pita, S., Ferreiro, M.J., Ferrandis, I., Lages, C., Pérez, R., Silva, A.E.,

16 Guerra, M. and Panzera, F. (2012). High dynamics of rDNA cluster location in kissing

17 bug holocentric chromosomes (Triatominae, Heteroptera). Cytogenetics and Genome

$18 \quad$ Research, 38(1), 56-67.

19 Pereira, J.O.P. (2006). Diversidade genética da abelha sem ferrão Melipona

20 quinquefasciata baseada no sequenciamento das regiões ITS1 parcial e 18S do DNA

21 ribossômico nuclear. Unpublished D. Phil. Thesis, Universidade Federal do Ceará,

22 Fortaleza, Brazil.

23 Pereira, T.T.P., Reis, A.C.C., Cardoso, D.C. and Cristiano, M.P. (2018). Molecular

24 phylogenetic reconstruction and localization of the (TTAGG)n telomeric repeats in the 
1 chromosomes of Acromyrmex striatus (Roger, 1863) suggests a lower ancestral

2 karyotype for leafcutter ants (Hymenoptera). Comparative Cytogenetics, 12(1), 13-26.

3 Pinkel, D., Straume, T. and Gray, J.W. (1986). Cytogenetic analysis using quantitative,

4 high-sensitivity, fluorescence hybridization. Proceedings of the National Academy of

$5 \quad$ Sciences of the United States of America, 83, 2934-2938.

6 Queiroz, E.C. (2015). Estudos moleculares em Acromyrmex Mayr, 1865. Unpublished

7 D. Phil. Thesis, Universidade Federal do Paraná, Curitiba, Brazil.

8 Roa, F. and Guerra, M. (2012). Distribution of 45S rDNA sites in chromosomes of 9 plants: structural and evolutionary implications. BMC Evolutionary Biology, 12(1), 11013.

11 Roy, V, Monti-Dedieu, L., Chaminade, N., Siljak-Yakovlev, S., Aulard, S., Lemeunier,

12 F., Montchamp-Moreau, C. (2005). Evolution of the chromosomal location of rDNA 13 genes in two Drosophila species subgroups: ananassae and melanogaster. Heredity, 14 94(4), 388-395.

15 Sánchez-Gea, J.F., Serrano, J. and Galián, J. (2000). Variability in rDNA loci in Iberian 16 species of the genus Zabrus (Coleoptera: Carabidae) detected by fluorescence in situ 17 hybridization. Genome $43,22-28$.

18 Santos, I.S., Mariano, C.S.F., Andrade, V., Costa, M.A., Delabie, J.H.C. and Silva, J.G.

19 (2010). A Cytogenetic Approach to the Study of Neotropical Odontomachus and 20 Anochetus Ants (Hymenoptera: Formicidae). Annals of the Entomological Society of 21 America, 103(3), 424-429.

22 Santos, I.S., Mariano, C.S.F., Delabie, J.H.C., Costa, M.A., Carvalho, A.F. and Silva, 23 JG. (2016). "Much more than a neck": karyotype differentiation between Dolichoderus 24 attelaboides (Fabricius, 1775) and Dolichoderus decollatus F. Smith, 1858 
1 (Hymenoptera: Formicidae) and karyotypic diversity of five other Neotropical species

2 of Dolichoderus Lund, 1831. Myrmecological News, 23, 61-69.

3 Schmid, M., Steinlein, C., Feichtinger, W. and Nanda, I. (2017). Chromosome banding

4 in Amphibia. XXXV. Highly mobile nucleolus organizing regions in Craugastor

5 fitzingeri (Anura, Craugastoridae). Cytogenetic and Genome Research, 152(4), 180-193.

6 Schmidt, C. (2013). Molecular phylogenetics of ponerine ants (Hymenoptera:

7 Formicidae: Ponerinae). Zootaxa, 3647(2), 201-250.

8 Schubert, I. and Lysack, M.A. (2011). Interpretation of karyotype evolution should

9 consider chromosome structural constraints. Trends in Genetics, 27(6), 207-216.

10 Schultz, T.R. and Brady S.G. (2008). Major evolutionary transitions in ant agriculture.

11 Proceedings of the National Academy of Sciences of the United States of America,

$12 \mathbf{1 0 5}(14), 5435-5440$.

13 Schweizer, D. (1980). Simultaneous fluorescent staining of R bands and specific

14 heterocromatic regions (DA/DAPI-bands) in human chromosomes. Cytogenetics and

15 Cell Genetics, 27, 190-193.

16 Sochorová, J., Garcia, S., Gálvez, F., Symonová, R. and Kovařík, A. (2018).

17 Evolutionary trends in animal ribosomal DNA loci: introduction to a new online

18 database. Chromosoma, 127, 141-150.

19 Solomon, S.E., Rabeling, C., Sosa-Calvo, J., Lopes, C.T., Rodrigues, A., Vasconcelos,

20 H.L., Bacci, Jr.M., Mueller, U.G. and Schultz, T.R. (2019). The molecular

21 phylogenetics of Trachymyrmex Forel ants and their fungal cultivars provide insights

22 into the origin and coevolutionary history of 'higher attine' ant agriculture. Systematic

23 Entomology, 44(4), 939-956. 
1 Št’áhlavský, F., Opatova, V., Just, P., Lotz, L.N. and Haddad, C.R. (2018). Molecular

2 technique reveals high variability of $18 \mathrm{~S}$ rDNA distribution in harvestmen (Opiliones,

3 Phalangiidae) from South Africa. Comparative Cytogenetics, 12(1), 41-59.

4 Sumner, A.T. (2003). Chromosomes: Organization and Function. Blackwell Publishing,

$5 \quad$ North Berwick, United Kingdom.

6 Symonová, R. (2019). Integrative rDNAomics - Importance of the oldest repetitive

7 fraction of the eukaryote genome. Genes, 10(5), 345-360.

8 Teixeira, G.A., Barros, L.A.C., Aguiar, H.J.A.C. and Pompolo, S.G. (2017).

9 Comparative physical mapping of $18 \mathrm{~S}$ rDNA in the karyotypes of six leafcutter ant

10 species of the genera Atta and Acromyrmex (Formicidae: Myrmicinae). Genetica, 145,

$11351-357$.

12 Teixeira, G.A., Barros, L.A.C., Lopes, D.M. and Aguiar, H.J.A.C. (2020). Cytogenetic

13 variability in four species of Gnamptogenys Roger, 1863 (Formicidae: Ectatomminae)

14 showing chromosomal polymorphisms, species complex, and cryptic species.

15 Protoplasma, 257, 549-560.

16 Vicari, M.R., Artoni, R.F., Moreira-Filho, O. and Bertollo, L.A.C. (2008).

17 Diversification of a ZZ/ZW sex chromosome system in Characidium fish (Crenuchidae,

18 Characiformes). Genetica, 134(3), 311.

19 Walker, L.I., Soto, M.A. and Spotorno, Á.E. (2014). Similarities and differences among

20 the chromosomes of the wild guinea pig Cavia tschudii and the domestic guinea pig

21 Cavia porcellus (Rodentia, Caviidae). Comparative Cytogenetics, 8(2), 153.

22 Ward, P.S., Brady, S.G., Fisher, B.L. and Schultz, T.R. (2015). The evolution of

23 myrmicine ants: phylogeny and biogeography of a hyperdiverse ant clade

24 (Hymenoptera: Formicidae). Systematic Entomology, 40, 61-81 
1 Zurita, F., Sánchez, A., Burgos, M., Jiménez, R. and de la Guardia, R.D. (1997).

2 Interchromosomal, intercellular and interindividual variability of NORs studied with

3 silver staining and in situ hybridization. Heredity, 78(3), 229-234. 